\title{
MUNKASZERVEZETI DETERMINIZMUS ÉS TÁVMUNKA
}

A földrajzi értelemben dekoncentrált munkaszervezetekben végzett munkafolyamatok vezetési szempontból való integrálása az emberi együttmúköodés új formáit igényli mind a munkavállalók, mind a vezetốk részéról. A távmunka nem csupán szervezeti kísérlet a költséghatékony termelésre, de a távmunkát végzố munkavállalók önmenedzselését, a vezetók részéról új munkaszervezési formák kialakítását is jelenti. Az Európai Uniónak a távmunkavégzés ösztönzésére vonatkozó, empirikus elemzésekre és vállalati igényekre támaszkodó irányelvei szemléletes példákat szolgáltatnak a tudományos eredmények és a gyakorlati igények összefonódására, illetve a kérdéskör fontosságára. Bár Magyarországon alacsony, ám kétségtelenül növekszik a távmunkavégzés aránya, így egyre több vezetési-szervezési problémát vet fel a vállalatvezetốk, illetóleg emberieróforrás-gazdálkodással, illetve szervezetfejlesztéssel foglalkozó szakemberek számára. A távmunka munkaszervezeti bevezethetôségének számtalan meghatározó tényezôje van, amelyek egy része olyan feltételektól függ, mint például az internet és a különbözố infokommunikációs technológiák (IKT) elterjedtségének mértéke. A távmunka-bevezetés feltételeinek másik csoportját a vállalaton belüli tényezók adják. A tanulmány az utóbbi tényezók közül kettôre, a technológiai fejlettség és a munkaszervezet jellegének meghatározó szerepére koncentrál, $s$ kis részben érinti a vezetői attitúdök kérdéskörét. Az elemzés egy nemzetközi kutatás eredményeinek újszerú elemzése révén von le következtetéseket. ${ }^{1}$

Kulcsszavak: távmunka, infokommunikációs technológia, mikro-, kis- és középvállalkozások, Európai Unió

A távmunka egyike azoknak az összetett társadalmi és gazdasági jelenségeknek, amelyekkel kapcsolatban a tudományos elemzések és a gyakorlati igények szoros összefonódása tapasztalható. Az alábbi tanulmányban leginkább vezetéstudományi, illetve szervezet- és munkaszociológiai elemzésekhez kívánok kapcsolódni. Ugyanakkor olyan szervezeti háttértényezők elemzésével, amelyek kiemelkedó szerepet töltenek be a távmunkavégzés elterjedését befolyásoló tényezók között, gyakorlati kérdések megválaszolásához is hozzájárulhatok. Tanulmányomban a távmunkavégzés munkaszervezeti bevezetését meghatározó szervezeti háttértényezők azonosításával és azok múködési mechanizmusaival foglalkozom. Célom egy olyan általános modellkísérlet megalkotása, amely egységes, kvantitatív keretek között elemzi a távmunkavégzés munkaszervezeti bevezetésével kapcsolatban fontos szervezeti háttértényezóket. Elemzésem empirikus alapját öt európai régió (Emilia-Romagna régió - Olaszország, Közép-dunántúli régió - Magyarország, Tamperei régió - Finnország, Nyugat-londoni régió - Egyesült Ki- rályság, Rhône-Alpes régió - Franciaország) összesen 1664 mikro-, kis- és középvállalatára vonatkozóan elvégzett kvantitatív felmérés adatai adják ${ }^{2}$.

Az elemzés során mind exploratív (feltáró), mind explanatív (magyarázó) igényekkel fel kívánok lépni. Elemzésem exploratív, amennyiben egy eddig kevéssé feltárt területról igyekszem információkat szolgáltatni. Az Európai Unión belül ugyanis - tudtommal - mindeddig nem készült olyan átfogó elemzés, ami a vizsgált vállalati méretkategóriákban, a regionális kontextus figyelembevételével kísérelt volna meg modellt alkotni a távmunkavégzés munkaszervezeti bevezetésére vonatkozóan. $^{3}$

$\mathrm{Az}$ említett exploratív kutatási igényeken kívül ugyanakkor explanatív követelményeknek is meg kívánok felelni az elemzés során, ugyanis a távmunkavégzés munkaszervezeti bevezetésével kapcsolatos oksági mechanizmusok kimutatására, vagyis modellezésére törekszem. Modellezés alatt azoknak a közvetlenül megragadható vagy latens módon hatást kifejtô tényezóknek a pontos megragadását és kvan- 
titatív jellemzését értem, amelyek befolyással vannak a távmunkavégzés munkaszervezetbe történô bevezetésére. A modellezés egyik legfontosabb célja, hogy a távmunkavégzés munkaszervezeti bevezetésére hatást gyakorló tényezốk különféle meghatározó szerepét mutassam be. Az infokommunikációs fejlettség elemzésével a technológiai determinizmus, a vezetói attitûdök elemzése révén a pszichológiai determinizmus, a szervezeti rugalmasság és a termelési paradigmák hatásainak tisztázásával pedig a munkaszervezeti determinizmus hatásainak tisztázására törekszem. Nem csupán a különbözố determinizmustípusok kimutatását, hanem azok egymáshoz képest értelmezett, relatív magyarázó erejét is igyekszem megragadni és kvantitatív szempontok alapján elemezni. E tekintetben arra keresem a választ, hogy az említett determinizmustípusok milyen mértékben járulnak hozzá ahhoz, hogy egy szervezet bevezeti-e a távmunkavégzést vagy sem. ${ }^{4}$ Modellemben a független változók kétféle típusát különítem el. A független változók első csoportját az ún. közvetlen vagy hagyományos szervezeti háttértényezók alkotják. Ezek közé olyan kemény szervezeti háttértényezők tartoznak, mint a szervezeti méret, a tevékenységi szektor és a tulajdonforma. A független változók második csoportját a közvetett vagy származtatott magyarázó változók képezik. Ezek a változók közvetlen mérési módszerekkel nem ragadhatók meg, kizárólag több szervezeti háttértényezô kombinációjának figyelembevételével, származtatott úton határozhatók meg. Jelenlétük tehát kizárólag hatásaik alapján, közvetett módszerekkel azonosítható a szervezetekben. A származtatott magyarázó változók közé a szervezet infokommunikációs technológiai fejlettségét, a vezetôii attitúdök különböző komponenseit, a szervezeti rugalmasság típusait és a szervezet által alkalmazott termelési paradigmákat soroltam. A fenti változócsoportok közül az utolsó kettő́t - tudtommal nem használták még modellalkotási szándékkal a távmunka bevezetésével kapcsolatban. Ezek a szervezeti háttértényező-típusok - összetett jellegükból adódóan - függő változóként szerepelnek a szervezetelemzések többségében. A legtöbb empirikus elemzés arra keresi a választ e tényezókkel kapcsolatban, hogy milyen közvetlen változók révén lehet azonosítani ezeknek a latens jellegzetességeknek a munkaszervezeti jelenlétét, mely szervezeti háttértényezók, illetve külső, például munkaeró-piaci feltételek vannak hatással a termelési paradigmák vagy a rugalmassági stratégiák különböző típusainak alkalmazására. Felállítandó modellem második újdonsága abban áll, hogy ezeket a latens szervezeti háttértényezóket is bevonom a távmunkavégzés munkaszervezeti bevezetésének modelljébe.
Az alkalmazott modell elemzésével tehát - járulékosan - a szervezeti rugalmassággal és a termelési paradigmákkal kapcsolatos szervezet- és munkaszociológiai vitákhoz is hozzá kívánok járulni. Arra keresek választ, hol helyezkedik el a szervezet által alkalmazott termelési paradigma és a rugalmassági stratégia a távmunkavégzés munkaszervezeti bevezetésére hatást gyakorló tényezốk sorában. A termelési paradigmák és a szervezeti rugalmasság kérdéskörei ugyanis központi jelentôségú, s részben egymással összefüggő kérdéscsoportjai a mai munka- és szervezetszociológiának, továbbá a vezetéstudománynak is. A téma mértékadó megközelítéseit képviselố kutatók között már a 70-es évektól kezdve parázs viták zajlanak a szervezeti rugalmasság és a termelési paradigmák definíciós kérdéseit, valamint a két témakör összekapcsolódásait illetôen. Napjaink szervezet- és munkaszociológiájában a rugalmasság-problematika egyik legelterjedtebb megközelítését a külsố és a belsố rugalmasság kategóriáinak elkülönítése, vagyis a szervezeti rugalmasság kétkomponensú megközelítése jelenti. A modellkísérletbe bevont magyarázó változók alkalmazásánál magam is erre a duális felosztásra támaszkodtam (Dahrendorf, 1986, 1995; Dore, 1986; Visser, 1999).

\section{A munkaszervezeti determinizmus tartalma: szervezeti rugalmasság és termelési paradigmák}

A rugalmasság kérdésköre a 70-es évektól kezdve van jelen nemcsak a munkavégzéssel és a munkafolyamattal kapcsolatos tanulmányokban (Piore - Sabel), hanem magában a gazdasági életben is. A rugalmasság követelményének megjelenése tehát körülbelül egybeesett a távmunkafogalom kialakulásával, ám tulajdonképpen egymástól független életet élő fogalmakról van szó, amelyek csak a 80-as, de még inkább a 90-es évektốl kezdve kapcsolódnak össze közvetlenül a távmunka szervezeti feltételeit tárgyaló elemzésekben. A rugalmasság problematika kapcsán kidolgozott munkaszociológiai modellek (pl. Makó - Simonyi, 2003) kiváló teoretikus segédeszközt jelentenek a távmunka bevezetéséhez szükséges feltételek szervezeti megközelítésú tanulmányozásához. A távmunkavégzés ugyanis nem más, mint eszköz a szervezetek számára a rugalmasság megteremtésére és a piaci talpon maradás esélyeinek növelésére, a versenyképesség fokozására. Amennyiben tehát operacionalizálható tartalmat sikerül adni a szervezeti rugalmasság fogalmának, olyan háttértényezốt nyerünk, amely nagyban hozzájárul a távmunka-bevezetés szervezeti gyakorlatának magyarázatához. Ebben a tekintetben tehát a távmunka bevezetését olyan munkaszervezeti jelenségként értelmezzük, amelynek hátterében - egyéb tényezókön kívül - a szervezet 
rugalmassági stratégiája áll. Az empirikus elemzésben arra teszek kísérletet, hogy az alább felvázolandó rugalmasságfogalom és az ide kapcsolódó ún. termelési paradigmák koncepciója alapján a távmunkavégzés munkaszervezetbe történó bevezetését magyarázzam meg egy kvantitatív modell alapján.

A munkafolyamaton belüli, mikroszintú rugalmasság és a makroszinten megnyilvánuló merevség kettôssége olasz empirikus kutatások alapján került be a nemzetközi munkaszociológiai fogalomtárba (Bruno, 1986), de erre vonatkozóan magyar kutatási eredmények is születtek (Neumann, 1988; Stark, 1988; Makó - Simonyi, 1990).

Napjaink szervezet- és munkaszociológiájában a rugalmasságproblematika kétkomponensú megközelítése Ralf Dahrendorf nyomán terjedt el (Dahrendorf, 1986). Az ún. szubjektív rugalmasság a munkafolyamatban résztvevók egyéni alkalmazkodóképességére, az objektív rugalmasság pedig a társadalmi, gazdasági, strukturális dimenziók által meghatározott feltételrendszer flexibilitására utal. Egy másik, szintén duális felosztás szerint a szervezetek kétféle rugalmasságát lehet megkülönböztetni. Az ún. belsó vagy funkcionális rugalmasság az alkalmazott munkaeró formális és informális tudásában, készségeiben és képességeiben jelenik meg, s pozitívan korrelál az adott munkaeró átlagos szaktudásának szintjével és szervezeti lojalitásának mértékével. Ebben a tekintetben nevezhető tehát a rugalmasságnak ez a típusa szubjektívnek. A külsó vagy munkaeró-piaci rugalmasság az alkalmazott munka- masság a szervezethez képest külső feltételektől függ, a rugalmasságnak ez a típusa objektívnak nevezhető. A két fogalompár (objektív-szubjektív, külsô-belsố) összefügg egymással, a következókben a külsô-belsố rugalmasság fogalmait használom. ${ }^{5}$

A kétféle rugalmasságstratégia tovább bontható annak alapján, hogy az adott stratégia alkalmazása az azt alkalmazó szervezet számára közvetlenül megtérülő, számszerûsíthetố eredményeket hoz-e, vagy hosszabb távon megtérülő, tartalmi, minóségi változásokkal jár-e együtt. A foglalkoztatás jogi feltételeire vonatkozó tényezók (például a határozott, illetve határozatlan idejú munkaszerződések) kvantifikálható, rövid távon megtérülő hasznot hozhatnak a szervezet számára, hiszen egy határozott idejú munkaszerződés lejártával a munkáltatót nem terhelik sem a munkaviszony megszüntetésével járó terhek (például végkielégítés), sem pedig további foglalkoztatási kötelezettségek. Ugyanígy számszerúsíthetô hasznot jelent a szervezet számára, ha a béralku folyamatát elôre tudja szabályozni a munkavállalókkal kötött bérmegállapodások révén. Az elóbbi példa a külsô, az utóbbi pedig a belsố rugalmasság előnyeire utal. A minőségi, tartalmi jellemzókkel leírható változások a vállalati értékteremtés módját, valamint a munkaszervezeti változások bevezetését érintik. Ilyen munkaszervezeti változás lehet például a távmunka bevezetése, de ide tartoznak olyan tényezók is, mint a bedolgozás, a kiszervezés vagy a csoportmunka bevezetése. A szervezeti rugalmasság típusait és azok jellemző vonásait az 1. táblázat foglalja össze. ${ }^{6}$

1. táblázat

\section{A szervezeti rugalmasság típusai és tartalma}

\begin{tabular}{|c|c|c|}
\hline & Számszerúsíthető & $\begin{array}{c}\text { Minőségi jellemzókkel } \\
\text { leírható }\end{array}$ \\
\hline $\begin{array}{l}\text { Külső (munkaerô-piaci) } \\
\text { rugalmasság }\end{array}$ & $\begin{array}{l}\text { Foglalkoztatási szerzódések } \\
\text { - határozott idejư munkaszerződés } \\
\text { - ideiglenes munkaszerződés } \\
\text { - idénymunka, szezonális munka } \\
\text { (reduktív rugalmasság) }\end{array}$ & $\begin{array}{l}\text { Termelési rendszerek } \\
\text { - alvállalkozások, kiszervezés } \\
\text { - kooperációs hálózatok, projektek } \\
\text { - külső szakértők } \\
\text { (teljesítménynöveló rugalmasság) }\end{array}$ \\
\hline $\begin{array}{l}\text { Belsố (funkcionális) } \\
\text { rugalmasság }\end{array}$ & $\begin{array}{l}\text { Munkaidó és bérmegállapodások } \\
\text { - munkakörmegosztás } \\
\text { - részmunka, túlmunka } \\
\text { - múszakbeosztások } \\
\text { (temporális rugalmasság) }\end{array}$ & $\begin{array}{l}\text { Munkaszervezet } \\
\text { - autonómia, csoportmunka } \\
\text { - képzés, belső tréning } \\
\text { - munkavállalói participáció } \\
\text { (munkaszervezeti rugalmasság) }\end{array}$ \\
\hline
\end{tabular}

erô lecserélhetôségéből, pótolhatóságából következik. A munkaerô-piaci rugalmasság annál nagyobb, minél nagyobb volumenú az adott munkaerô-piaci szegmens kínálati oldala, és többnyire negatívan korrelál a munkaerő átlagos szaktudásának szintjével és szervezeti lojalitásának mértékével. Mivel a munkaerô-piaci rugal-
A rugalmassági stratégiák a szervezetek emberierőforrás-gazdálkodási praxisát jelző ideáltípusok, így önmagukban nem fordulnak elő, a gyakorlatban a fenti kategóriák hibridformáival találkozhatunk. Az 1. táblázat mátrixának egyes mezóiben tulajdonképpen olyan gazdálkodási eszközök szerepelnek, amelyek alkalma- 
zása a szervezet hosszú, illetve rövid távú stratégiája alapján is változhat. Rövid távon - például a hirtelen szükségessé váló túlmunka elvégzése érdekében - egy szervezet építhet a szezonális munka számszerúsíthetô előnyeire (külsố rugalmasság), ugyanakkor a hosszú távú stratégiájában megjelenhet a munkavállalók lojalitására építő többletmunka elvárása is (belsô rugalmasság). Mivel a gyakorlatban egyszerre több rugalmassági stratégiát is alkalmazhat ugyanaz a szervezet, a gyakorlatban csak közelítô modelleket lehet kidolgozni arra nézve, hogy az egyes szervezetek melyik rugalmassági stratégiát alkalmazzák intenzívebben.

Arugalmasság kérdéskörével kapcsolatos viták a 80as évekre eljutottak az ún. termelési paradigmák koncepciójához. Atermelésszervezési paradigmákban azok a latens tényezók jelennek meg, amelyek a szervezet „kemény” adatai révén közvetlenül nem azonosíthatók, ám nagyban meghatározzák a szervezetek magatartását a gazdasági környezetben. A szervezeti magatartás vizsgálati lehetôségei közé tartozik az említett, latensen megjelenó termelésszervezési paradigmák vizsgálata és tipizálása. A távmunkavégzés bevezetésének szervezetszociológiai szempontú vizsgálatában kiemelt jelentősége van a termelési paradigmáknak, ezek ugyanis olyan szervezeti mintákat hoznak létre, amelyek valamely adott szervezet esetében a távmunkavégzésnek a munkaszervezetbe való bevezetése vagy az elutasítása irányába hatnak. A termelési paradigmák azonosítása révén tehát egy kulcsfontosságú tényezốcsoportot határolunk körül a távmunka bevezetését előrelendítő és fékezô tényezốk közül.

A munkavégzés szerkezetében, vagyis az ún. feladatkörnyezetben végbemenô változások elemzése az 1980-as évektôl egyre fontosabbá válik a munka- és szervezetszociológiai kutatásokban. A 80-as évek közepén megfogalmazott „új termelési koncepció" (Kern - Schumann, 1984; Liker - Fruin - Adler, 1999) hatására a munkaszociológiai viták intenzitása felerôsödött. ${ }^{7}$ A különbözô elméleti megközelítések elsôsorban az újonnan megjelenố technológiák (például IT, IKT) növekvő mértékú elterjedésével, valamint a termék-, szolgáltatás- és munkaerôpiacokon végbement strukturális változások bekövetkezésével magyarázták a munkaszervezetben megjelenó változásokat (Sabel, 1982; Piore - Sabel, 1984). A termelési paradigmák átrendezôdésének leírására számos modell született, amelyeket itt részletesen nem tárgyalok. ${ }^{8}$ A termelési paradigmákkal kapcsolatos megközelítések kiemelt vitapontja a taylori és fordi elvek munkaszervezeti megjelenésének, illetve továbbélésének kérdésköre. Az ún. „munkafolyamat-iskola"9 képviselói között folyamatos vita van a taylori és fordi munkaszervezési eljárások továbbélésének módjáról és azok módosulásáról. Az irányzat érdeklődésének központjában a különbözố technológiák, különösen az infokommunikációs technológiák által a termelési paradigmákra gyakorolt hatások állnak. Ez a megközelítés a távmunkavégzés szervezeti keretrendszerére vonatkozó vizsgálatok szempontjából központi jelentőségú. A munkafolyamat-iskola egyes képviselői a „posztfordizmus” megjelenését hangsúlyozzák (Sandberg, 1995), ami nagyfokú önállóságon alapuló, kreatív munkavégzési formák kialakulását és terjedését foglalja magában. A posztfordizmus szakítást jelent a fordi munkaszervezési eljárások közvetlen ellenőrzésen és szoros felügyeleten alapuló modelljével, és a munkavállalói önállóságot hangsúlyozza. Az irányzat más képviselői - empirikus kutatási eredmények alapján - a neofordista törekvések dominanciáját hangsúlyozzák a munkafolyamatban (Huys - Sels - Van Hootegem - Bundersvoet - Hendenrickx, 1999), amelyek a szigorú ellenőrzésre, a hatáskörök felosztására és a hierarchia erősítésére építenek.

A munkafolyamattal kapcsolatos szociológiai elemzések sajnos nem egységesen használják a „,neo-” és a „,poszt-" elótagokat, a neofordi és a posztfordi munkaszervezet elkülönítésére alkalmas két tényezô megítélésében azonban bizonyos mértékú konszenzus mutatkozik. Az elsố tényezó az ellenőrzés jellegére vonatkozik: míg a neofordi munkaszervezetben szoros, közvetlen vezetést vagy automatikus teljesítménymérést alkalmaznak, addig a posztfordi formákban a munkavállalók ellenőrzése terén a határidốk meghatározását és az egyéni vagy csoportcélok definiálását helyezik elôtérbe - ezeket közvetett felügyeleti formáknak is nevezik. A második tényezó a munkafeladatok jellegére vonatkozik: míg a neofordi munkaszervezetet pontosan meghatározott, esetleg standardizált feladatok jellemzik, amelyek végrehajtásáért az egyén a felelős, addig a posztfordi formákban a csoportcélok megvalósítására, illetve az egyénnek a célok meghatározásába történő bevonására helyezik a hangsúlyt.

A továbbiakban - a fent leírt tényezókre alapozva - a „,neo-" és a „poszt-" előtagokat eredeti (ógörög, illetve latin) jelentésüknek megfelelően használom. A neofordi munkaszervezeten a taylori és fordi munkaszervezési eljárások evolutív, mutációs újramegjelenését értem (Huys - Sels - Van Hootegem - Bundervoet - Henderick, 1999), míg a posztfordizmus alatt olyan munkaszervezetet értek, amely eltávolodik a taylori és fordi elvektől, a munkavállalók önállóságára, kreativitására épít, s a felügyelet és a kontroll alternatív formái jelennek meg benne (Sandberg, 1995). ${ }^{10}$ 
A posztfordi munkaszervezet kapcsán gyakran a posztmodern szervezet egyik típusáról beszélnek (Clegg, 1990), amely a gyakorlatban leginkább a japán üzleti szervezetekben jelenik meg, kontrasztot alkotva a modern, neofordi munkaszervezettel. A modern-posztmodern, illetve neofordi-posztfordi fogalompárok a szakirodalomban sokszor párhuzamosan bukkannak fel (McGrath - Houlihan, 1998; Harris, 1998), tehát inkább ideáltípusként foghatók fel. Ugyanakkor nem szabad elfelejteni, hogy a két paradigma által jelzett munkaszervezeti jellegzetességek gyakran keverednek, hibridformákat hozva létre. Elméleti értelemben tehát inkább egy skáláról beszélhetünk, amelynek az egyik végén a szoros kontrollra és standardizált feladatokra épító neofordizmus, a másikon pedig a munkavállalói önállóságra és kreatív munkafeladatokra épító posztfordizmus munkaszervezete áll, és a két végpont közötti hibridformák száma gyakorlatilag végtelen. A fogalmak általam történő használatát a 2. táblázatban foglalom össze. megadása. Mivel ez a modell jelentósen eltér az eredeti fordi modelltôl, az eltérés kifejezésére a „poszt” elootagot használom.

Nagy számban léteznek továbbá olyan kevert munkaszervezeti megoldások is, amelyeknél a neofordi és a posztfordi paradigmák keverednek egymással: ezeket a továbbiakban hibrideknek fogom nevezni, kétféle kevert munkaszervezetet (A hibrid és B hibrid) értve alatta.

\section{A minta és az alkalmazott módszerek}

A kérdőíves adatfelvételt megelőzóen a nemzetközi kutatói teamnek választ kellett találnia arra a módszertani problémára, hogy a távmunkavégzés munkaszervezeti jelenléte és egy sor ehhez kapcsolódó szervezeti jellegzetesség a vizsgált régiók mikro-, kis- és középvállalatai körében nem egyenletes eloszlást mutat. A távmunkavégzés pontos eloszlását nem ismertük, csupán azzal a feltételezéssel élhettünk, hogy a mikrovállalatok

2. táblázat

A neofordi és posztfordi paradigma: a fogalomhasználat összefoglalása

\begin{tabular}{|c|c|c|c|}
\hline \multicolumn{4}{|c|}{ A munkafeladatok meghatározásának módja } \\
\hline \multirow{3}{*}{ Az ellenốrzés jellege } & & Standardizált feladatok & Egyéni és csoportautonómia \\
\cline { 2 - 4 } & Közvetlen & NEOFORDI & $\begin{array}{c}\text {,B” HIBRID (posztfordi } \\
\text { feladatszerkezet + neofordi } \\
\text { kontroll) }\end{array}$ \\
\cline { 2 - 4 } & Közvetett & $\begin{array}{c}\text { „A" HIBRID (posztfordi kontroll + } \\
\text { neofordi feladatszerkezet) }\end{array}$ & POSZTFORDI \\
\hline
\end{tabular}

A továbbiakban tehát neofordi munkaszervezeten az olyan típusú szervezeteket értem, amelyekben az ellenôrzés hagyományos, közvetlen formái standardizált feladatokkal kombinálódnak. Az eredeti fordi üzemekben a standardizált feladatokat a futószalag alkalmazásával, a közvetlen, szoros felügyeletet pedig a munkafelügyelók és a gyári rendőrség alkalmazásával oldották meg. Az automatizáció, de fóleg (napjainkban) az infokommunikációs technológiák elterjedésével természetesen mind a felügyelet formája, mind a munkafeladatok standardizálásának módja finomodott, de - a fordi üzemekben a kontroll még szorosabbá tétele érdekében alkalmazott fizikai erőszakot leszámítva - jellegét tekintve nem tér el jelentősen a fordi modelltól. Ezért használom a ,neo-” elótagot ennek a munkaszervezetnek a megkülönböztetésére, utalva arra, hogy itt valójában a fordi munkaszervezési elvek újbóli megjelenéséról van szó.

A posztfordi modell ugyanakkor a munkavállalói autonómiára épít a feladatok meghatározásában, a munkafolyamat ellenôrzésénél pedig olyan közvetettebb formákat alkalmaz, mint például a határidők körében kevésbé terjedt el a távmunka. Ennek a feltételezésnek rendeltük alá a mintavételi eljárást.

A kutatás során rétegzett, nem arányos mintavételi eljárást alkalmaztunk, amely alkalmas a fenti probléma kiküszöbölésére. Az eljárás elsố lépéseként az öt régió alapsokaságát alkotó mikro-, kis- és középvállalatokat régiónként különítettük el (1. réteg), majd az egyes régiókon belül hoztunk létre viszonylag homogén csoportokat az alkalmazotti létszám révén operacionalizált szervezeti méret kategóriái alapján (2. réteg). Ezt követően egyszerú véletlen mintavételi eljárást alkalmazva, az egyes régiókban külön-külön rendelkezésre álló adatbázisok alapján, számítógép által generált véletlenszámok segítségével hoztuk létre a mintát.

A mintavétel második jellegzetessége, a ,nem arányos" mintavételi eljárás alkalmazása azt jelenti, hogy a kisvállalkozásoknak az alapsokaságbeli arányaikhoz képest nagyobb esélyt biztosítottunk a mintába kerülésre. Erre a távmunkavégzés munkaszervezeti jelenlétének eloszlására vonatkozó fenti feltételezésünk miatt volt szükség. Az eljárás alkalmazása miatt a kisvállal- 
kozások felülreprezentáltak a mintában, a tevékenységi szektorra nézve azonban a minta reprezentatív. A reprezentativitás biztosítására a szervezeti méreten és a tevékenységi szektoron kívül nem érvényesítettünk egyéb szervezeti háttértényezốt a mintakészítés során.

$\mathrm{Az}$ ismertetett módszer segítségével a kiválasztott öt európai régióban összesen 1664 szervezetet kérdeztünk meg, telefonos interjúk (CATI) alkalmazásával (3. táblázat). ${ }^{11}$ (magyarázó) jellegú megállapításokat tenni. A modellezés fő eszköze egy olyan logisztikus regresszióelemzési eljárás (logit egyenlet), amelynek függő változója a távmunkavégzés munkaszervezeti jelenléte (van/nincs távmunkavégzés a szervezetben), független változói pedig különféle szervezeti háttértényezók.

Az elsố lépésben a távmunkavégzés munkaszervezeti bevezetésére hatást gyakorló tényezóket azonosítom, az egyes változók áttételes hatásainak kiszúré-

A minta régiónkénti összetétele a szervezeti méret alapján

\begin{tabular}{|c|c|c|c|c|c|c|}
\hline & & \multirow[b]{2}{*}{$(\mathrm{N}, \%)$} & \multicolumn{3}{|c|}{ Szervezeti méret } & \multirow{2}{*}{$\begin{array}{c}\text { Összesen } \\
(\mathbf{N}, \%)\end{array}$} \\
\hline & & & $\begin{array}{c}\text { mikrovállalat } \\
\text { (0-9 fó) }\end{array}$ & $\begin{array}{c}\text { kisvállalat } \\
\text { (10-49 fó) }\end{array}$ & $\begin{array}{c}\text { középvállalat } \\
\text { (50-249 fố) }\end{array}$ & \\
\hline \multirow{10}{*}{ Régió } & \multirow{2}{*}{ Emilia-Romagna } & $\mathrm{N}$ & 124 & 339 & 25 & 488 \\
\hline & & $\%$ & $25,4 \%$ & $69,5 \%$ & $5,1 \%$ & $100,0 \%$ \\
\hline & \multirow{2}{*}{ Közép-Dunántúl } & $\mathrm{N}$ & 51 & 194 & 40 & 285 \\
\hline & & $\%$ & $17,9 \%$ & $68,1 \%$ & $14,0 \%$ & $100,0 \%$ \\
\hline & \multirow{2}{*}{ Tampere } & $\mathrm{N}$ & 70 & 198 & 37 & 305 \\
\hline & & $\%$ & $23,0 \%$ & $64,9 \%$ & $12,1 \%$ & $100,0 \%$ \\
\hline & \multirow{2}{*}{ Nyugat-London } & $\mathrm{N}$ & 28 & 217 & 58 & 303 \\
\hline & & $\%$ & $9,2 \%$ & $71,6 \%$ & $19,1 \%$ & $100,0 \%$ \\
\hline & \multirow{2}{*}{ Rhône-Alpes } & $\mathrm{N}$ & 40 & 198 & 45 & 283 \\
\hline & & $\%$ & $14,1 \%$ & $70,0 \%$ & $15,9 \%$ & $100,0 \%$ \\
\hline \multirow{2}{*}{\multicolumn{2}{|c|}{ Összesen $(\mathbf{N}, \%)$}} & $\mathbf{N}$ & 313 & 1146 & 205 & 1664 \\
\hline & & $\%$ & $18,8 \%$ & $68,9 \%$ & $12,3 \%$ & $100,0 \%$ \\
\hline
\end{tabular}

A kialakított kérdőívet telefonos interjúk útján „kérdeztük le", interjúalanyaink a mintába került cégek elsô számú vagy funkcionális vezetői, illetve általuk felhatalmazott olyan személyek voltak, akik - beosztásuk révén - releváns válaszokat tudtak adni a céggel kapcsolatos kérdésekre.

Fố célom a távmunkavégzés munkaszervezeti bevezetésére hatást gyakorló szervezeti tényezôk azonosítása és a hatások mibenlétének pontos megragadása. Nem a távmunkavégzés bevezetésében meglévô különbségek leírása a célom, hanem egy olyan általános modell kísérleti megalkotása, amely alkalmas a távmunka bevezetésére hatást gyakorló tényezók elemzésére, valamint az azonosított tényezókre jellemzó hatásmechanizmusok múködésének megragadására is.

Elemzésem kvantitatív szemléletú, és meg is marad a kvantitatív elemzések lehetôségei és korlátai között, amin azt értem, hogy elsősorban matematikai statisztikai módszerek alkalmazása révén kimutatható szervezetszociológiai összefüggések feltárására törekszem. Az elemzés során igyekszem mind exploratív (feltáró), mind explanatív sével. Ennek a lépésnek az elvégzésével képet adok a távmunkavégzés bevezetésére hatást gyakorló tényezôkrốl. Az elemzés második lépésében a regionalitás dimenziójának a távmunkavégzés bevezetésére gyakorolt hatását elemzem, megvizsgálva, hogy a teljes mintán értelmezett összefüggések megragadhatók-e az egyes régiókban. Az elemzésnek ebben a lépésében a fő kérdés az, hogy vajon hasonló törvényszerúségek múködnek-e az egyes régiókban a távmunkavégzés bevezetésének feltételeivel kapcsolatban, vagy az egyes régiókban eltérô mechanizmusok hatásai érvényesülnek.

\section{A modell függố változója és a független változók csoportjai}

A távmunkát alkalmazó cégek azonosítását (függő változó) annak alapján végeztem el, hogy lehetôvé teszik-e saját munkavállalóik számára egyidejúleg a külső helyszínen történô munkavégzést, illetve a vállalat infokommunikációs struktúrájához való távoli hozzáférést. 
Az elemzés során tehát a távmunkavégzés munkaszervezeti jelenlétét vizsgálom (van távmunka/nincs távmunka egy szervezetben), és nem foglalkozom azzal a folyamattal, amelynek során a távmunkavégzés beépül a szervezet rutin munkafolyamataiba. Elkerülendố a fogalmi zavarokat, elôre kell bocsátanom, hogy a továbbiakban a „távmunkavégzés munkaszervezeti bevezetése” és a „távmunkavégzés munkaszervezeti jelenléte" kifejezéseket szinonimaként használom.

A független változók egyik általam elkülönített típusát alkotó ún. közvetlen magyarázó változók csoportjába három szervezeti háttértényezố tartozik: szervezeti méret; tevékenységi szektor; tulajdonforma.

A modell közvetlen magyarázó változói tulajdonképpen hagyományos, ún. „kemény” szervezeti háttértényezók. A modellben való szerepeltetésük magától értetődő, kiegészítő magyarázatot nem igényel, hiszen olyan alapjellemzókról van szó, amelyek elengedhetetlenül szükségesek bármilyen empirikus igényekkel fellépó szervezetelemzéshez.

A modell független változóinak második típusát a közvetett vagy származtatott magyarázó változók képezik. Ehhez a típushoz itt a következô változócsoportok sorolhatók: IKT-fejlettség; vezetói attitúdök; szervezeti rugalmasság; termelési paradigmák.

$\mathrm{Az}$ „IKT-fejlettség” a távmunkavégzés munkaszervezeti bevezetésének szükséges feltételét jelenti, ezért megkerülhetetlen a modellbe való beépítése. Az IKT-fejlettség kapcsán tulajdonképpen az általános technológiai fejlettségnek egy speciális szegmenséról van szó, mégsem lehet azt az általános technológiai fejlettséggel megegyezóként tárgyalni, mivel kizárólag az infokommunikációs eszközök alkalmazásának fejlettségét jelenti. (Az IKT-fejlettség és az általános technológiai fejlettség a szervezetek többségénél természetesen összefügg egymással.)

A vezetói attitüdök a vizsgált vállalati méretkategória miatt bírnak különös jelentőséggel. A kisebb vállalati méretkategóriákban ugyanis a szervezeti hierarchia laposabb jellege miatt a döntések kevesebb szervezeti filteren haladnak keresztül, s így kézenfekvô azzal a hipotézissel élni, hogy a távmunka bevezetésével kapcsolatos stratégiai döntésekben tompítatlanabb módon jelentkezhetnek a vezetối attitúdök, mint a nagyvállalati méretkategóriában, ahol a vezetối döntéseknek egy sor szervezeti automatizmuson kell keresztülmenniük, és azokat számos külsố tényezô (például az igazgatótanács és/vagy a kisrészvényesek véleménye mint döntéshozatali szempont) is befolyásolja.

A szervezeti rugalmasságnak a modellben való szerepeltetése szintén kézenfekvő, hiszen a távmunka mint új munkavégzési forma bevezetésének egyik leg- fontosabb előnye abban áll, hogy általa a munkavégzés térbeli és idôbeli flexibilitásának kiaknázásával növelni lehet a szervezeti rugalmasságot. A távmunkavégzés munkaszervezeti modellezésénél tehát potenciális meghatározó tényezóként kell számolni a szervezeti rugalmasság különféle típusaival.

A termelési paradigmák olyan közvetett szervezeti háttértényezók, amelyek a szervezeti magatartás majdnem minden elemére kihatással vannak. Egy új típusú munkavégzési formának a munkaszervezetbe való bevezetésével kapcsolatban tehát alapos okkal feltételezhetô, hogy a bevezetés sikeressége valamilyen módon függ a szervezetre jellemzô termelési paradigma típusától. Következésképpen a termelési paradigmákat olyan, a távmunkavégzés munkaszervezeti bevezetését meghatározó latens tényezóknek kell tekintenünk, amelyek - más feltételek állandósága esetén - elősegíthetik, de gátolhatják is a távmunkavégzés implementálását a munkaszervezetben.

A felsorolt szervezeti háttértényezók (közvetlen, illetve származtatott magyarázó változók) egyszerre vannak jelen a szervezetekben, így bonyolult kombinációik révén, egymásra gyakorolt áttételes hatásokon keresztül, fejtik ki befolyásukat a távmunkavégzés munkaszervezeti bevezetésére. A szóban forgó hatásmechanizmusokat összetettségük miatt kvalitatív módszerekkel viszonylag egyszerúbb azonosítani, mint számszerúsítésre törekvő elemzésekkel, ám ez utóbbi vállalkozás sem reménytelen. Kvantitatív elemzésekkel kizárólag akkor lehet pontos képet adni a távmunkavégzés munkaszervezeti bevezetését meghatározó tényezókról, ha az említett összetett hatásokat elkülönítjük egymástól, ideáltipikus sémák, tiszta hatások megragadására törekedve. A távmunkavégzés modellezése során ezt a feladatot fogom elvégezni. A modell újdonságából adódik, hogy a származtatott szervezeti háttértényezók tárgyalását - nem függő́, hanem független változóként kezelve azokat - új kontextusba helyezi. A távmunka bevezetésére potenciális hatást gyakoroló szervezeti háttértényezóket és az azok közötti kapcsolatokat a 1. ábra foglalja össze, amely modellkísérletem vázlatos összefoglalásának is tekinthetô.

A 1. ábrán a modellkísérletbe bevonandó szervezeti háttértényező́k fontosabb összefüggés-rendszereit tüntettem fel. A távmunkavégzés munkaszervezeti bevezetésére közvetlen befolyást gyakoroló összefüggéseket a függó változóra gyakorolt közvetlen hatásoknak nevezem $(\rightarrow)$. Ilyen közvetlen hatás például az IKTfejlettségnek a távmunkavégzés bevezetésére gyakorolt hatása. Összesen 8 közvetlen hatást különítettem el a modellben. 
A távmunkavégzés

munkaszervezeti bevezetésének modellje

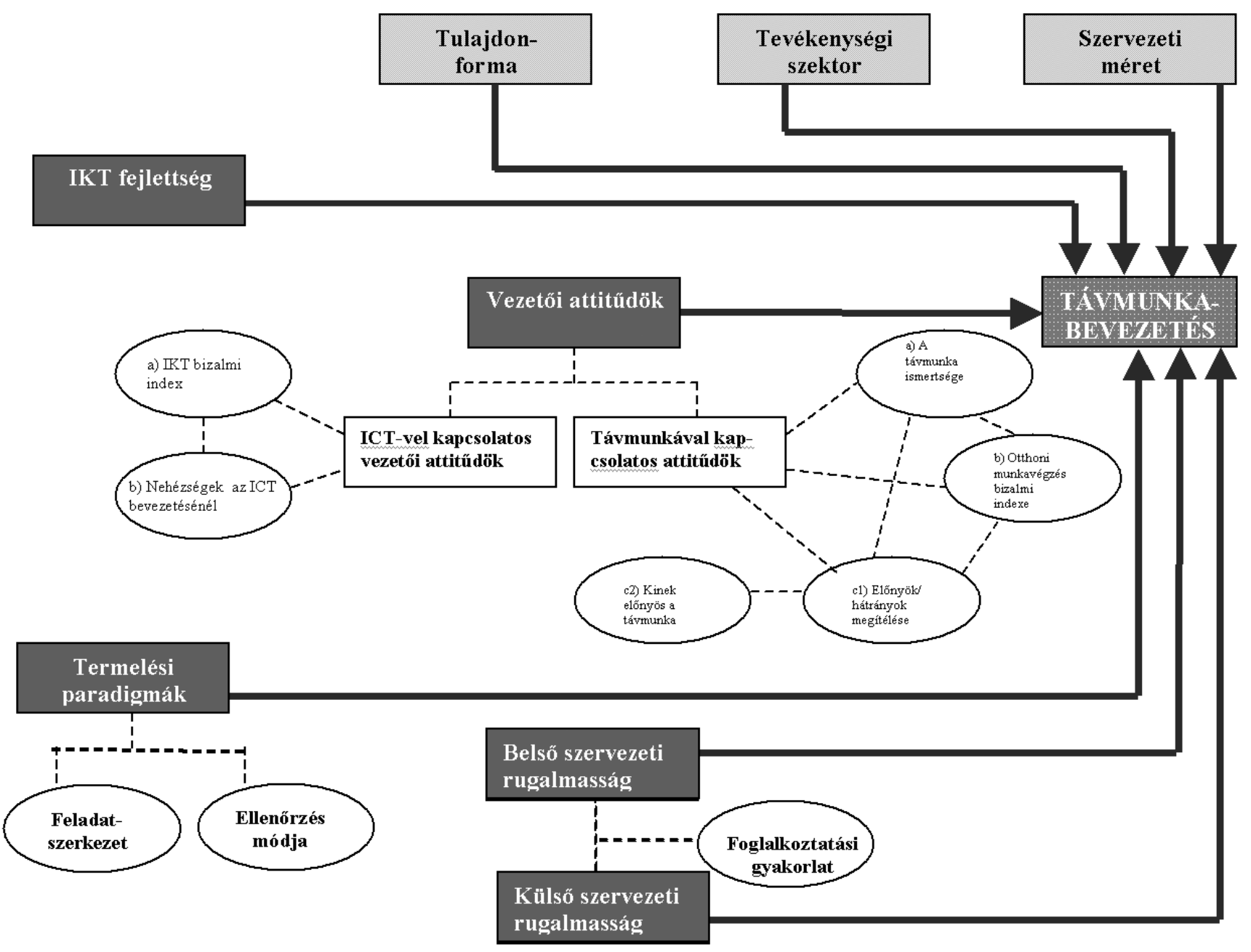

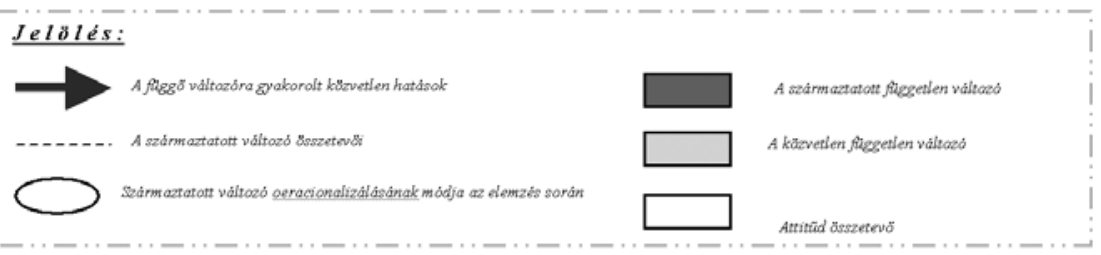

Fontos megjegyezni, hogy más jellegú, az ábrán nem szereplő összefüggés-típusok is jelen vannak a modellben. Ezek a magyarázó változók közötti kölcsönhatásokban jelentkeznek, és a szervezeti háttértényezók egymás közötti kapcsolatait jelzik. A tevékenységi szektor például hatással lehet az IKTfejlettségre, vagy akár az alkalmazott termelési paradigmára, illetve a szervezeti rugalmasság stratégiájára is. A hatás fordított irányban is érvényesülhet: a termelési paradigma jellege meghatározhatja, hogy egy szervezet mennyit áldoz infokommunikációs eszközeinek 
hanem kizárólag a rendelkezésre álló adatok alapján, a deklarált korlátok figyelembevételével megragadható összefüggésekre koncentrálok. Az alkalmazandó modell a távmunkavégzés munkaszervezeti bevezetésének csupán egy lehetséges modellje. Nem zárható ki annak a lehetôsége, hogy a távmunka bevezetésével kapcsolatban több oksági mechanizmus is múködik egymással párhuzamosan, sốt minden bizonnyal végtelen sok ilyen mechanizmus létezik. Mindezeknek a maradéktalan kimutatása természetesen reménytelen vállalkozás, arra viszont reális esély van, hogy a sok mechanizmus közül egyet megragadjunk. Az itt kifejtett elemzéssel kizárólag egy, és csak egy lehetséges magyarázó mechanizmust kísérelek meg bemutatni, nem kizárva egyéb párhuzamos magyarázatok létezésének a lehetőségét. Ugyanakkor a megalkotandó modellnek meg kell felelnie a tudományos magyarázatok iránt támasztott falszifikációs kritériumnak: az adott modell egyetlen belsố cáfolat esetén irrelevánssá válik. A falszifikációs kritérium természetesen csak a belsố cáfolatokra vonatkozik, $\mathrm{s}$ fennáll az a lehetőség, hogy a megalkotott magyarázatot az empirikus tesztelés alapján kapott eredmények figyelembevételével korrigáljuk, pontosítsuk. Ennek értelmében tehát a fenti modellt olyan kiindulásnak tekintem, amit az empirikus tesztelés eredményei alapján az alábbiakban pontosítani fogok. A modell elókészítése során elvégzett kétváltozós elemzések (lásd Keszi, 2005) viszonylag részletes, de semmiképpen sem elégséges mélységú információkat szolgáltattak a vizsgált régiók mikro-, kisés középvállalatainak a távmunkavégzés bevezetésében alkalmazott gyakorlatáról. A kétváltozós elemzések által nyitva hagyott kérdések megválaszolásának, illetve a távmunkavégzés munkaszervezeti bevezetését meghatározó tényezók pontos azonosításának érdekében két lépésben végzek logisztikus regresszióanalízist. ${ }^{13}$

\section{Empirikus eredmények}

\section{I. modell: a teljes minta alapmodellje}

Az elsố lépés fő kérdése a következó: a kutatás során vizsgált szervezeti háttértényezók közül - az áttételes hatásokat kontroll alatt tartva - melyekról jelenthető ki egyértelmúen, hogy hatást gyakorolnak a távmunkavégzés munkaszervezeti bevezetésére. Az elemzés során alkalmazott logisztikus regressziós modell (logit egyenlet) függó változója a távmunkavégzés munkaszervezeti bevezetése, független változói pedig a fentiekben ismertetett közvetlen és származtatott magyarázó változók. Az elemzés során megvizsgáltam a független változók többféle kombinációját. A számításokból adódó végsố modellt (a logit egyenlet eredményeit) a 4. táblázat mutatja be.
A végsố modellben - a változók áttételes hatásainak kiszúrésével - a megvizsgált 13 (3 közvetlen +10 származtatott) független változó közül a távmunkavégzés munkaszervezeti bevezetésénél a következő 5 változó bizonyult statisztikailag szignifikánsnak: ${ }^{14}$

- termelési paradigma,

- szervezeti méret,

- IKT fejlettség,

- tevékenységi szektor,

- külsố rugalmasság.

A 4. táblázatban szereplố adatok többváltozós matematikai statisztika „nyelvén” azt mutatják, hogy egy szervezet milyen eséllyel vezeti be munkaszervezetébe a távmunkát az ún. „referenciakategóriába” tartozó szervezetekhez képest. ${ }^{15}$

\section{A modellben szereplő változók tartalma}

\section{A függó́ változó: távmunka-bevezetés}

A modellben a távmunkát bináris állapotnak tekintettem: vagy alkalmazza egy szervezet ezt a munkavégzési formát, vagy nem. Nem foglalkoztam a távmunka munkafolyamatokba való beépülésének módjával, illetôleg mélységével. A függő változó azonosítását a nemzetközi távmunka-kutatások során bevett két dimenzió mentén azonosítottam: a) külsố helyszínen történő munkavégzés és b) a munkavégzés során a vállalat infokommunikációs struktúrájához való távoli hozzáférés engedélyezése a munkavállalók számára. Ennek a változónak két értéke van: $0=$ nincs távmunka (a fenti kettő közül legalább az egyik feltétel nem teljesül), 1 = van távmunka (mindkét feltétel teljesül).

\section{Az IKT-fejlettségi index}

Az általános IKT-fejlettséget mutató változó megalkotásánál különböző fontossággal (súlyozva) vettem figyelembe a kutatás során vizsgált 7 infokommunikációs technológia vállalati gyakorlatban való jelenlétét. Az IKT-változó megalkotásánál figyelembe vett változókat és a hozzájuk rendelt súlyokat az 5. táblázat mutatja.

Módszertani döntést igényelt, hogy a fent szereplô súlyok meghatározásánál milyen elvet követek. A döntésben az MTA Szociológiai Kutatóintézetben folytatott korábbi - más témában kapott - kutatási eredményeinket vettem alapul (Keszi - Makó - Illéssy - Mester, 2003: 15-16.; Makó - Keszi - Mester, 2004: 208-209.). Többféle származtatott mutatót határoztam meg az általános IKT-fejlettség jellemzésére nézve, a mutatók megbízhatóságát intervallum és ordinális szinten is teszteltem. A jelen tanulmányban ismertetett modellben használt IKT-változót a fenti listában szereplő súlyok hozzárendelésével határoztam meg. A kapott IKT-változó magasabb értéke az adott vállalat 
A távmunkavégzés bevezetésének modellje - Változók az egyenletben

\begin{tabular}{|c|c|c|c|c|c|c|c|}
\hline Változó & $\begin{array}{l}\text { Regressziós } \\
\text { paraméter } \\
\text { (B érték) }\end{array}$ & $\begin{array}{c}\text { Standard } \\
\text { hiba (S.E.) }\end{array}$ & Wald érték & $\begin{array}{l}\text { Szabad- } \\
\text { ságfok } \\
\text { (df) }\end{array}$ & $\mathbf{R}$ érték* & $\mathbf{S}$ & $\begin{array}{c}\text { Esély- } \\
\text { hányados } \\
\text { Exp (B) }\end{array}$ \\
\hline $\begin{array}{l}\text { TERMELÉSI PARADIGMA } \\
\text { (referenciakategória: NEOFORDI) }\end{array}$ & & & 22,474 & 2 & 0,103 & $\mathbf{0 , 0 0 0}$ & \\
\hline HIBRID & 0,443 & 0,149 & 8,914 & 1 & 0,063 & 0,003 & 1,558 \\
\hline POSZTFORDI & 0,735 & 0,155 & 22,407 & 1 & 0,108 & 0,000 & 2,085 \\
\hline $\begin{array}{l}\text { SZERVEZETI MÉRET } \\
\text { (referenciakategória: } \\
\text { MIKROVÁLLALAT) }\end{array}$ & & & 18,894 & 2 & 0,092 & $\mathbf{0 , 0 0 0}$ & \\
\hline KISVÁLLALAT & 0,087 & 0,157 & 0,306 & 1 & 0,000 & 0,580 & 1,091 \\
\hline KÖZÉPVÁLLALAT & 0,835 & 0,220 & 14,389 & 1 & 0,084 & 0,000 & 2,305 \\
\hline IKT FEJLETTSÉG & $\mathbf{0 , 0 9 0}$ & 0,016 & 33,570 & 1 & 0,135 & $\mathbf{0 , 0 0 0}$ & 1,095 \\
\hline $\begin{array}{l}\text { SZEKTOR } \\
\text { (referenciakategória: GYÁRTÁS) }\end{array}$ & & & 17,763 & 4 & 0,075 & 0,001 & \\
\hline ENERGIA-SZEKTOR & 0,570 & 0,436 & 1,712 & 1 & 0,000 & 0,191 & 1,768 \\
\hline LOGISZTIKA, KOMMUNIKÁCIÓ & 0,345 & 0,178 & 3,766 & 1 & 0,031 & 0,052 & 1,412 \\
\hline PÉNZÜGY & $-0,446$ & 0,319 & 1,960 & 1 & $-0,000$ & 0,162 & 0,640 \\
\hline $\begin{array}{l}\text { INGATLAN- ÉS EGYÉB ÜZLETI } \\
\text { SZOLG. }\end{array}$ & 0,464 & 0,138 & 11,376 & 1 & 0,073 & 0,001 & 1,591 \\
\hline $\begin{array}{l}\text { KÜLSŐ RUGALMASSÁG } \\
\text { (referenciakategória: } \\
\text { NEM JELLEMZÖ) }\end{array}$ & & & 21,616 & 3 & 0,095 & $\mathbf{0 , 0 0 0}$ & \\
\hline ALACSONY SZINTÚ & 0,471 & 0,167 & 7,940 & 1 & 0,058 & 0,005 & 1,602 \\
\hline KÖZEPES SZINTÚ & 0,702 & 0,175 & 16,154 & 1 & 0,090 & 0,000 & 2,017 \\
\hline MAGAS SZINTŰ & 0,796 & 0,191 & 17,338 & 1 & 0,094 & 0,000 & 2,218 \\
\hline KONSTANS $\left(\mathrm{B}^{0}\right)$ & $-2,262$ & 0,204 & 122,476 & 1 & $-0,263$ & $\mathbf{0 , 0 0 0}$ & 0,104 \\
\hline
\end{tabular}

A modell illeszkedésének mutatói:

\begin{tabular}{|c|c|c|c|c|c|c|}
\hline Modell $\chi^{2}$ & df & S & -2LL & Cox-Snell-féle $\mathbf{R}^{\mathbf{2}}$ & Nagelkerke-féle $\mathbf{R}^{\mathbf{2}}$ & Találati arány \\
\hline 202,832 & 12 & 0,000 & 1729,709 & 0,130 & 0,177 & $67,7 \%$ \\
\hline
\end{tabular}

Az IKT fejlettséget mutató változó létrehozásánál figyelembe vett eszközök és a hozzájuk rendelt súly

\begin{tabular}{|l|c|}
\hline \multicolumn{1}{|c|}{ IKT eszköz } & $\begin{array}{c}\text { Az IKT fejlettséget mutató változónál } \\
\text { hozzárendelt súly }\end{array}$ \\
\hline $\left.\mathrm{X}_{\mathrm{a}}\right)$ E-mail használat biztosítása a dolgozóknak & $(1 \mathrm{x})$ \\
\hline $\left.\mathrm{X}_{\mathrm{b}}\right)$ Internetböngészó rendelkezésre állása a munkatársak számára & $(1 \mathrm{x})$ \\
\hline $\left.\mathrm{X}_{\mathrm{c}}\right)$ Vállalaton belüli számítógépes hálózat (Intranet) & $(2 \mathrm{x})$ \\
\hline $\mathrm{X}_{\mathrm{d}}$ ) Csoportmunkaszoftver használata a munkavégzés során (Groupware Systems $)$ & $(3 \mathrm{x})$ \\
\hline $\left.\mathrm{X}_{\mathrm{e}}\right)$ Videokonferencia használata & $(4 \mathrm{x})$ \\
\hline $\left.\mathrm{X}_{\mathrm{f}}\right)$ Saját weboldal megléte & $(3 \mathrm{x})$ \\
\hline $\left.\mathrm{X}_{\mathrm{g}}\right)$ Internetes értékesítés (Sales Online) & $(5 \mathrm{x})$ \\
\hline
\end{tabular}


infokommunikációs technológiai fejlettségének magasabb szintjét jelzi. A változó értéke 0-19 között változik ( 0 , ha a cég egyetlen technológiát sem alkalmaz, 19, ha az összes vizsgált eszközt használja) ${ }^{16}$.

\section{A termelésiparadigma-változó}

A termelési paradigma változójának operacionalizálását a 2. táblázatban szereplő elméleti alapvetésekre támaszkodva végeztem el, az ott szereplő mátrix-struktúra alapján, két tényezô figyelembevételével. Az ellenôrzés - jellege szerint - lehet közvetlen, amely során szoros felügyeletet vagy automatikus teljesítménymérést alkalmaznak a vállalatok, vagy közvetett, melynek során határidók definiálásával, csoportcélok meghatározásával vagy egyéb alternatív vezetési módszerekkel végzik a munkavállalók vagy teamek ellenôrzését.

A munkafeladatok jellege modellünk alapján szintén kétféle lehet: standardizált, amely pontosan körülírt, szigorúan ellenőrzött feladatokat foglal magában, amelyek teljesítése során a munkavállalóknak nincs, vagy csekély mértékú döntési/mérlegelési autonómiája van, vagy autonómiára épító, amely során már a feladatok körülhatárolásában is fontos szerepe van a teameknek, illetőleg az abban tevékenykedő munkavállalóknak. A termelési paradigma változóját a fentiek szerint operacionalizálva nominális mérési szintú változót kaptunk, melynek kategóriái és jelentése szintén a 2. táblázatból olvasható le.

\section{A szervezetirugalmasság-változó}

A szervezeti rugalmasság változójának operacionalizálását, az 1. táblázatban szereplő elméleti megfontolásokra támaszkodva végeztem el, a rendelkezésre álló adatbázis engedte lehetôségek kihasználásával, a 6. táblázatban szereplók szerint.

Mivel a kétféle rugalmassági stratégia párhuzamosan vanjelen a szervezetek múködésében, az operacionalizálás

\section{A szervezeti rugalmasság operacionalizálása} a nemzetközi adatbázis adatai alapján

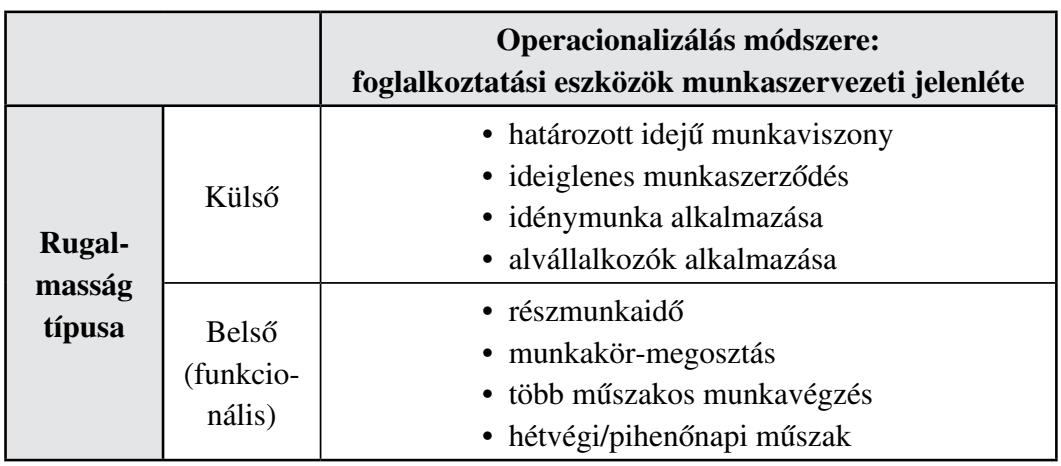

célja az volt, hogy a kétféle rugalmassági stratégia intenzitását megragadjam, és a szervezetekhez olyan konkrét, ordinális mérőszámokat rendeljek, amelyek külön-külön jellemzik a szervezetet a külsô és a belsô rugalmasság alkalmazásának intenzitásával kapcsolatban. Mindkét rugalmasságtípus értéke 0-4-ig változhat, attól függóen, hogy a 6. táblázat mátrixában szereplő foglalkoztatási eszközök közül mennyit alkalmaz a szervezet. 0 érték esetén nem jellemző a szervezetre az adott rugalmasságstratégia alkalmazása, a 4-es érték az adott rugalmasságstratégia magas szintű jelenlétére utal.

Belátható, hogy az említett operacionalizálási folyamat révén definiált szervezeti rugalmasságtípusok eltérő jellegú tényezókre építő stratégiákat foglalnak magukban. Míg a reduktív és a teljesítménynövelő rugalmasságtípusokat magában foglaló külső rugalmasság a szerződésekre és merev termelési rendszerekre, addig a temporális és a munkaszervezeti rugalmasság kategóriáit magában foglaló belső rugalmasság a meglévő emberi erôforrásokkal való (idő)hatékonyabb gazdálkodásra, vagyis közvetve a munkavállalók lojalitására épít.

\section{A szervezeti méret és a tevékenységiszektor-változók}

E két „kemény” szervezeti háttértényező operacionalizálását európai uniós standardok alapján azonosítottuk. A szervezeti méretnél az alkalmazotti létszámot vettuik figyelembe (0-9 fő: mikro-, 10-49 fő: kis-, 50249 fő: közép-, 249 fő<: nagyvállalat). A tevékenységi szektor esetében pedig a szervezet alapító okiratában lévő SEA (Sectors of Economic Activities) kódok alapján alakultak ki ennek a változónak az értékei.

\section{A modell értelmezése}

A modell értelmezését a változók sorrendjében, a 4. táblázatban fentrôl lefelé haladva a jobb oldali oszlopban szereplő esélyhányadosok értékeinek áttekintésével kezdhetjük meg.

6. táblázat

A termelési paradigmák esetében a hármas tagolású felosztás (a hibridformák összevonásával) statisztikailag megbízhatónak bizonyult, ami azt (is) jelenti, hogy az egyes hibridformák között nem állnak fenn olyan különbségek, amelyek a távmunkavégzés munkaszervezeti bevezetésével kapcsolatos esélyeket jelentősen befolyásolnák. A termelési paradigmák esetében a neofordi paradigmát tekintettem referenciakategóriának, vagyis ehhez a kategóriához viszonyítottam a másik két kategóriához tartozó szervezetek (hibrid, posztfordi) távmunka-bevezetésének esélyeit. Az esélyhányados azt fe- 
jezi ki, hogy az adott kategóriába tartozó szervezeteknek - a referenciakategóriához képest - hányszoros esélyük van a távmunkavégzés bevezetésére. A 4. táblázatban található esélyhányadosok azt jelzik, hogy a neofordi termelési paradigmához viszonyítva a hibridparadigmához tartozó szervezeteknek másfélszeres (1,558-szeres), a posztfordi paradigmához tartozó szervezeteknek pedig több mint kétszeres (2,085-szeres) esélyük van a távmunkavégzésnek a munkaszervezetbe történő bevezetésére. Ezek az értékek arra az esetre vonatkoznak, amikor a táblázatban szereplő többi változó kombinált és áttételes hatásait kiszúrtük. A termelési paradigma változó kategóriái közötti különbségek statisztikailag is szignifikánsak, így kijelenthető, hogy a különféle termelési paradigmákhoz tartozó szervezetek esetében jelentős különbségek tapasztalhatók a távmunkavégzés bevezetésének esélyeivel kapcsolatban: a legnagyobb esélye a posztfordi paradigmához, a legkisebb esélye a neofordi paradigmához tartozó szervezeteknek van, a hibridparadigmák pedig a távmunkavégzés bevezetésének esélyeit tekintve valahol középen helyezkednek el.

A szervezeti méret szintén jelentôs magyarázó változónak bizonyult a modellben. Ennél a változónál a mikrovállalatokat tekintettem referenciakategóriának, ehhez képest értelmezhetốk a másik két vállalati méretkategória esélyhányadosai. Látható, hogy a kisvállalati szektor a távmunkavégzésben csekély mértékben tér el a mikrovállalatoktól (a távmunka bevezetésének esélye a kisvállalatoknál 1,09-szeres), viszont a középvállalati szektor esetében már jelentôs különbségek tapasztalhatók: a középvállalatok távmunka-bevezetési esélye a mikrovállalatokhoz képest - amennyiben a többi magyarázó változó hatásait kontroll alatt tartjuk - több mint kétszeres (2,305). Az esélyhányadosok, illetve a hozzájuk tartozó szignifikanciaszintek összehasonlításából immár az is világossá vált, hogy a távmunkavégzés bevezetése szempontjából a mikro- és kisvállalati szektorok nem térnek el egymástól számottevően, ugyanakkor a középvállalatok jelentôs, kb. kétszeres különbséget mutatnak a másik két méretkategóriához képest.

A szervezetek IKT-fejlettsége szintén statisztikailag szignifikáns tényezônek bizonyult a távmunkavégzés bevezetésével kapcsolatban. Mivel ennél a változónál nem jelöltem ki referenciakategóriát, az esélyhányados kommentálásának nincs sok értelme, ${ }^{17}$ az adat értelmezéséhez azonban fontos rámutatni, hogy a többi független változó áttételes és összetett hatásainak kiszúrése után az IKT-fejlettség bizonyíthatóan jelentős befolyással van a távmunkavégzés bevezetésének esélyére. Az IKT-fejlettség hatásának kérdésére a független változók relatív erôssége kapcsán még visszatérek.
A tevékenységi szektorokban a gyártó cégek 1-nek vett távmunka-bevezetési esélyétól az energiaszektorhoz tartozó cégek térnek el leginkább: az ide tartozó vállalatoknál a távmunkavégzés bevezetésének esélye több mint másfélszeres $(1,768)$ a gyártó cégekhez képest. Az ingatlan- és egyéb üzlettel foglalkozó cégek, valamint a logisztikai és kommunikációs vállalatok esélyhányadosa szintén $\mathrm{kb}$. másfélszeres $(1,59$, illetve $1,41)$, vagyis ez a három kategória nem tér el jelentősen egymástól a függó változó alakulásában. A pénzügyi szektorba tartozó mikro-, kis- és középvállalatoknak ugyanakkor a gyártó cégekhez képest kisebb esélyük van a távmunkavégzés munkaszervezeti bevezetésére: a 0,64-es esélyhányados azt jelzi, hogy a pénzügyi tevékenységet végzố cégeknek - a többi szervezeti háttértényező hatásának kiszürésével végzett elemzés eredményei alapján - a gyártó cégekhez képest kevesebb mint kétharmadnyi (64\%-os) esélyük van a távmunka bevezetésére.

A szervezeti rugalmasságtípusok közül a külsố rugalmasság stratégiája mutat kapcsolatot a távmunkavégzés bevezetésével. Ennél a változónál négy csoportba soroltam a szervezeteket: az elsố csoportba azok a vállalatok tartoztak, amelyekre egyáltalán nem jellemzó a külsó rugalmasság stratégiájának alkalmazása, a fennmaradó három kategóriába pedig a külsố rugalmasság alkalmazásának intenzitása alapján kerültek a szervezetek (alacsony/közepes/magas szintú külsố rugalmasság). A logisztikus modellben azokat a szervezeteket tekintettem referenciának, amelyekre egyáltalán nem jellemzó a külsố rugalmasság. Mint az esélyhányadosok alakulásából látható, a külső rugalmasság intenzitásának növekedésével növekszik a távmunka bevezetésének esélye is. Már azoknak a szervezeteknek is több mint másfélszeres (1,602-szeres) esélyük van a távmunkavégzés bevezetésére, amelyek alacsony szintú külsố rugalmasságot mutatnak, a magas szintú külsố rugalmassággal jellemezhetô vállalatoknak viszont több mint 2,2-szeres (2,218-szeres) esélyük van ennek a munkavégzési formának az alkalmazására - azokhoz a vállalatokhoz képest, amelyekre egyáltalán nem jellemző az ilyen fajta rugalmasságstratégia alkalmazása.

A fentiekben áttekintett független szervezeti háttértényezókkel kapcsolatban lényeges kérdés, hogy az egyes változók milyen relatív (egymáshoz képest értelmezett) magyarázó eróvel bírnak a távmunkavégzés bevezetésében. Ennek a kérdésnek a megválaszolására az R mutatót alkalmaztam. ${ }^{18}$

A szignifikáns magyarázó erôvel bíró szervezeti háttértényezók közül a három származtatott független változó rendelkezik a legnagyobb relatív magyarázó erôvel a modellben. Az IKT-fejlettségnek van a leg- 
nagyobb magyarázó ereje, rögtön ezután következnek a termelési paradigmák, majd a külsố rugalmasság. A külsố rugalmasságtól nem sokkal marad el a szervezeti méret, majd a tevékenységi szektor változója. Ezek az adatok azt bizonyítják, hogy a származtatott magyarázó változók nem csupán szignifikáns tényezőnek számítanak a távmunkavégzés munkaszervezeti bevezetésével kapcsolatos magyarázó modellben, de relatív magyarázó erejük erôsebb a közvetlen szervezeti háttértényezốk hatásánál. Messzemenókig indokolt volt tehát a közvetlen háttértényezókön kívül a közvetlenül nem mérhetô, latens szervezeti háttértényezóket is meghatározni és bevonni a távmunkavégzés magyarázatára felhasználható modellbe.

A logit modell áttekintésének segítségével választ kaptunk arra a kérdésre, amelyet a kétváltozós elemzés eredményei alapján nem sikerült megválaszolni: a távmunkavégzés munkaszervezeti bevezetésére a vizsgált szervezeti háttértényezók közül öt tényezố gyakorol hatást. A származtatott független változók közül a termelési paradigma, az IKT-fejlettség mértéke, valamint a külsố szervezeti rugalmasság szintje, a közvetlen magyarázó változók közül pedig a szervezeti méret és a tevékenységi szektor hatása mutatkozik szignifikánsnak. Az említett hatások a többi változó hatását kontroll alatt tartva, az áttételes hatások kiküszöbölése esetén is fennállnak.

A logit modell választ adott ugyanakkor további lényegi kérdésekre is, amelyek a kétváltozós elemzés kapcsán merültek fel. Az alábbiakban ezeket tekintem át.

A kétváltozós elemzés eredményeinek felhasználásával nem volt eldönthetô, hogy vajon fenntartható-e az a hipotézis, miszerint a neofordi és posztfordi munkaszervezetek egy ideáltipikus skála két végpontját jelölik a távmunka bevezetésekor is. A logit egyenlet áttekintése és értelmezése révén azonban egyértelmú válasz fogalmazható meg erre a kérdésre: A neofordi és a posztfordi paradigmához tartozó munkaszervezetek a távmunkavégzés munkaszervezeti bevezetése szempontjából szintén egy ideáltipikus skála két végpontjának tekinthetôk, hiszen a többi változó hatásának kontroll alatt tartása esetén az esélyhányadosok e kétfajta termelési paradigma esetében szignifikánsan különböznek egymástól. A posztfordi paradigmához tartozó szervezeteknek a neofordihoz képest több mint kétszeres esélyük van a távmunkavégzés munkaszervezeti bevezetésére, ugyanakkor a hibridformák valahol a neofordi és posztfordi paradigma között „,félúton” helyezkednek el. A kapott eredmények alapján természetesen kizárólag a szervezeti magatartásnak a távmunkavégzés bevezetésére vonatkozó részével kapcsolatban foglalhatunk állást. A paradigmák a szervezeti magatartásnak több lényeges elemére hatással vannak, mivel azonban a kutatás során kizárólag a távmunkavégzés munkaszervezeti bevezetését vizsgáltuk, csak ezzel kapcsolatban jelenthetjük ki, hogy egy olyan ideáltipikus skála végpontjairól van szó, amelyet a neofordi paradigmához tartozó munkaszervezetek alacsony és a posztfordi paradigmához tartozó szervezetek magas távmunka-bevezetési hajlandósága jellemez.

A termelési paradigmáknál a kétváltozós elemzések kapcsán további kérdésként fogalmazódott meg, hogy a különféle hibridparadigmák között a távmunka bevezetési esélyeinél tapasztalt eltérések esetében vajon inherens különbségekkel, vagy pedig más szervezeti háttértényezốk áttételes hatásának megjelenésével állunk-e szemben. Erre a kérdésre szintén egyértelmú válasz adható, ugyanis, ha az egyes hibrideket elkülönítve vonjuk be a modellbe, akkor kimutathatók bizonyos szerény különbségek a két végpont közötti spektrum különbözó pontjain elhelyezkedő hibridtípusok között (például egy „A” hibrid esélyhányadosa a spektrumnak a neofordi paradigmához közelebb esố részén 1,349, míg egy „B” hibridé a posztfordi szélső érték közelében 1,946), ezeknek a hibrid termelési ,paradigmáknak" a magyarázó ereje azonban nem szignifikáns. Összességében tehát a hibridek közötti különbségekre vonatkozó hipotézis a rendelkezésre álló adatok alapján nem verifikálható.

A szervezeti rugalmasság szintén érdekes kérdéseket vetett fel, a kétváltozós elemzések során ugyanis nem volt megnyugtatóan bizonyítható, hogy a kétféle rugalmasságtípus közül melyik hat egyértelmúen a távmunkavégzés bevezetésére, valamint az sem, hogy milyen szerepe van a kétféle rugalmasságot magában foglaló általános szervezeti rugalmasságnak, empirikusan alátámasztható-e a különböző rugalmasságistratégiák elkülönítése a távmunkavégzés bevezetésének magyarázata szempontjából. A logit modell alkalmazása révén erre a kérdésre is egyértelmú válasz adható. A távmunkavégzés munkaszervezeti bevezetése szempontjából ugyanis egyértelmúen a külsô vagy munkaerô-piaci rugalmasság stratégiája bizonyult lényeges meghatározó tényezônek. (A magas szintû külsô rugalmassággal rendelkezô mikro-, kis- és középvállalatoknak több mint 2,2-szeres esélyük van a távmunka bevezetésére azokhoz a szervezetekhez képest, amelyekre nem jellemző a külső rugalmasság stratégiájának alkalmazása). Minél inkább épít a külsố rugalmasság stratégiájára a szervezet, annál nagyobb esélye van a távmunkavégzés bevezetésére (természetesen itt is a többi szervezeti háttértényező hatásának kiszúrése mellett). A belső vagy funkcionális rugalmasság és a szervezet általános rugalmassága ugyanakkor egyértelmúen nincs hatással a távmunka 
munkaszervezeti bevezetésére. Ez az eredmény feltétlenül összhangban van a szervezeti rugalmassággal kapcsolatban megfogalmazott elméleti tételekkel: a külső vagy munkaeró-piaci rugalmasság minőségi jellemzókkel leírható típusa, az ún. „teljesítménynövelő rugalmasság" valószínúsíti az olyan új típusú termelési rendszerek alkalmazását, mint a kiszervezés, a külsố kooperációs hálózatok, vagy a külső szakértő́k alkalmazása. Az ilyen új típusú termelési rendszerek közé sorolható a távmunkavégzés is, ami szoros összefüggést mutat a szervezet külső rugalmasságával.

A mikro-, kis- és középvállalatok vezetôinek attitúdjeivel kapcsolatos inkonzisztenciák kérdése, illetve annak megválaszolása, hogy jelentős hatással vannak-e a vezetôi beállítódások a vizsgált vállalati szegmensben a távmunka bevezetésére, szintén fontos problémákat vetett fel. A kétváltozós elemzések eredményei alapján gyanítható volt, a logit modell eredményei nyomán pedig egyértelmúen alátámasztható, hogy a vezetôi attitüdök nem befolyásolják szignifikánsan a távmunkavégzés munkaszervezeti bevezetését. Meg- jegyzendő ugyanakkor, hogy a vezetôi beállítódások vizsgálata önálló kutatásként is megállja a helyét. Reális lehetôség ugyanis, hogy léteznek olyan attitúdkomponensek, amelyekról a jelenleg vizsgált adatok alapján nem tudunk semmilyen kijelentéseket tenni, ám ezek is hatással lehetnek a távmunka bevezetésére vonatkozó döntésekre. Ilyenek például a csoportos munkavégzés (teammunka) igényével kapcsolatos vezetôi beállítódások, de az olyan összetett tényezók is, mint a vezetési stílus, ami befolyással lehet például a „vizuális kontroll" igényére - ez utóbbi viszont áttételesen meghatározhatja a távmunkavégzés munkaszervezeti bevezetése iránti vezetối attitûdöket. A vezetối attitúdök tehát - a vizsgált adatok tanúsága alapján - nincsenek befolyással a távmunkavégzés bevezetésére, de nem zárható ki annak a lehetősége, hogy a kutatás során nem vizsgált egyéb attitűdkomponensek jelentôs hatást gyakorolnak a távmunka bevezetésének esélyeire.

Eredeti kiindulásunkat (1. tábla) alapul véve tehát az alábbi ábrán szereplő összefüggésrendszer tekinthetố a távmunka-bevezetés végsố modelljének (2. ábra).

A távmunka-bevezetés tesztmodelljének eredményei

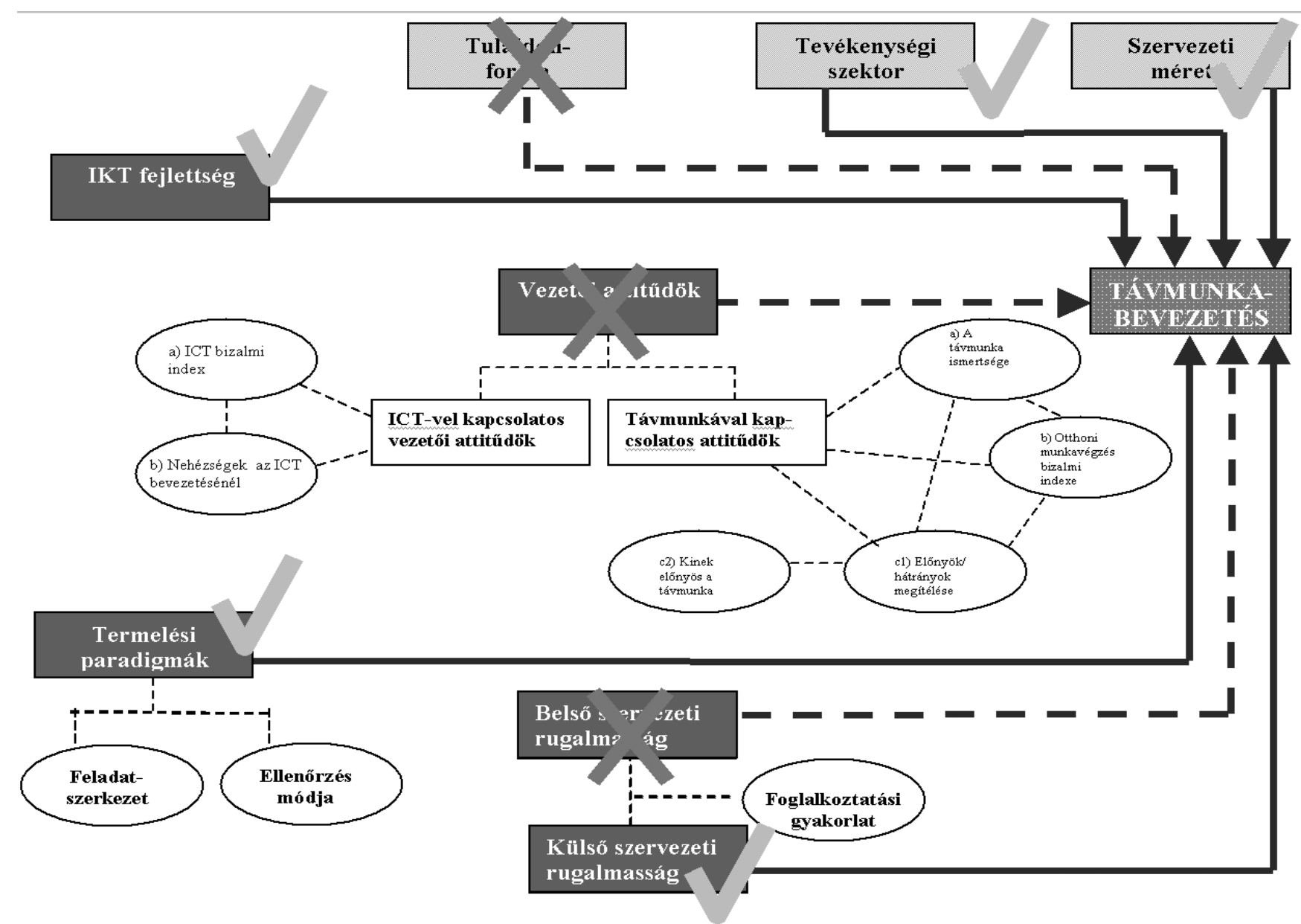


A kiinduló nyolc szervezeti háttértényezó közül ötról bebizonyosodott, hogy szignifikáns hatással van a távmunkavégzés munkaszervezeti bevezetésére, három változó esetében pedig nem kaptunk statisztikailag alátámasztható összefüggéseket. Összességében tehát a vizsgált régiók mintáján - a modellben maradt öt változó révén - sikerült megragadni a vizsgált új munkavégzési formára hatást gyakorló latens tényezốk összefüggéseit. Az alkalmazott eljárás segítségével önálló hatásokat sikerült kimutatni az egyes háttérváltozók kombinációiból adódó latens, összetett és áttételes hatások kiszúrésével.

\section{II-IV. modell: a regionális különbségek modelljei}

A következő fontos lépés az elemzés teljessé tételében annak megvizsgálása, hogy a teljes mintán értelmezett logisztikus modell révén megragadott öszszefüggések érvényesülnek-e az egyes régiókban. $\mathrm{Ne}$ felejtsük el, hogy a teljes mintán végzett elemzéseknek nem a regionális különbségek feltárása volt a célja, hanem olyan általános modellkísérlet megalkotása, amely a távmunka bevezetésére hatást gyakorló tényezóket azonosítja. Ennek a célnak a fenti modell meszszemenókig eleget tett. Egyelőre nem rendelkezünk viszont információkkal arra nézve, hogy a megalkotott modell ugyanúgy „múködik-e” minden régióban. Vajon ugyanazok a hatásmechanizmusok és ugyanolyan módon vannak-e jelen, mint amit az általános modell mutat? Ezt a kérdést azért kell megvizsgálni, mert egyáltalán nem vehetố eleve biztosra, hogy a fentiekben bemutatott összefüggések az egyes régiók különböző társadalmi-gazdasági adottságai, kulturális összetétele és történelmi tradíciói, valamint makrogazdasági feltételei által meghatározott regionális mikrokörnyezetekben azonos módon fejtik ki hatásukat.

A regionális összefüggések és az általános modell alapján kidolgozott magyarázó mechanizmus relevanciájának tesztelése érdekében a teljes mintára vonatkozó modellen kívül (I. modell) további három regionális modellt vizsgáltam meg (II-IV. modell), és mindhárom modell esetében teszteltem az I. modellnél kapott öszszefüggések fennállását.

A II. modell (a földrajzi régiók modellje) esetében az egyes földrajzi régiókat vizsgáltam külön-külön, itt tehát maga a geográfiai értelemben vett hovatartozás volt a kategorizálás alapja. A III. modell (a fejlett/fejletlen régiók modellje) esetében a távmunkavégzés munkaszervezeti bevezetése terén észlelt különbségeket érvényesítettem a regionális tagolásban, a kétváltozós elemzések alapján fejletlenebbnek mutatkozó Emilia-Romagna régiót és Közép-Dunántúlt elkülönítve a magasabb távmunka-penetrációt mutató Tamperei, Nyugat-londoni és Rhône-Alpes régióktól. A IV. modell (az élenjáró régiók modellje) esetében az infokommunikációs tekintetben legfejlettebb két régiót, a Tamperei és a Nyugat-londoni régiót vetettem külön vizsgálat alá, feltételezve, hogy az IKT-fejlettségben megjelenô kiugró regionális teljesítmények hatással lehetnek a távmunkavégzés bevezetését befolyásoló tényezók múködési mechanizmusaira is.

7. táblázat

Szignifikáns tendenciák az egyes régiómodellekben

\begin{tabular}{|c|c|c|c|c|c|}
\hline MODELLEK & Paradigma & $\begin{array}{c}\text { Szervezeti } \\
\text { méret }\end{array}$ & $\begin{array}{c}\text { IKT- } \\
\text { fejlettség }\end{array}$ & Szektor & $\begin{array}{c}\text { Külsô } \\
\text { rugalmasság }\end{array}$ \\
\hline I. MODELL: A teljes minta alapmodellje & + & + & + & + & + \\
\hline \multicolumn{6}{|l|}{ II. MODELL: A földrajzi régiók modellje } \\
\hline \multicolumn{6}{|l|}{ Emilia-Romagna } \\
\hline Közép-Dunántúl & & & + & + & \\
\hline Tampere & & + & + & & \\
\hline Nyugat-London & & & + & & \\
\hline Rhône-Alpes & & + & + & & + \\
\hline \multicolumn{6}{|l|}{ III. MODELL: A fejlett/fejletlen régiók modellje } \\
\hline Emilia-Romagna, Közép-Dunántúl & & + & & & \\
\hline Tampere, Nyugat-London, Rhône-Alpes & + & + & + & & + \\
\hline \multicolumn{6}{|l|}{ IV. MODELL: Az élenjáró régiók modellje } \\
\hline Tampere, Nyugat-London & & + & + & & \\
\hline
\end{tabular}

Jelmagyarázat: +: Legalább 5\%-os szinten szignifikáns változók 
A különbözó régiómodellek elkülönítése azt a célt szolgálta, hogy a térbeli tagoltság dimenziója minél több tekintetben vizsgálat alá vonható legyen. Összesen háromféle vonatkozásban vizsgáltam tehát meg a regionalitás dimenzióját. ${ }^{17} \mathrm{Az}$ egyes modellek esetében szignifikánsnak bizonyult szervezeti háttértényezôket a 7. táblázat foglalja össze.

$\mathrm{Az}$ egyes régiómodelleket egymástól függetlenül vizsgáltam, vagyis a modellek elkülönítésével és tesztelésével tulajdonképpen megkíséreltem az alapmodell (I.) több szempontú falszifikálását. Három különböző kiindulásból teszteltem, hogy a kiinduló modellben megfogalmazott mechanizmusok múködésére lehet-e ellenpéldát találni. A három tesztmodell egyikében sem találtam az eredeti modellben megfogalmazott magyarázó mechanizmusokkal ellentétes tendenciát. Arra természetesen volt példa, hogy az alapmodellben magyarázó erôvel bíró változó a részmintán értelmezett modellben nem bizonyult szignifikánsnak, ez azonban nem tekinthetố az eredeti modell cáfolatának, hanem kizárólag annyit jelent, hogy a modell alapján az adott változó hatása nem bizonyítható.

Két jelentôs eredményre hívom fel a figyelmet. Az elsố abban áll, hogy a vizsgált öt változó közül kettő - nevezetesen a közvetlen szervezeti háttértényezók közül a szervezeti méret, a származtatott független változók közül pedig az IKT-fejlettség - statisztikailag szignifikáns magyarázó tényezőnek bizonyult a tesztelt modellek nagyobb részében.

A másik jelentôs eredményre a III. regionális modell vizsgálata során bukkantam: az alapmodellben szignifikánsnak bizonyult öt tényezó közül négy a fejlett régiók esetében szintén szignifikánsnak bizonyult. Ennek az eredménynek az alapján feltételezhetô, hogy az alapmodell révén megragadott összefüggésrendszer a gazdaságilag, illetve infokommunikációs tekintetben egyaránt fejlettebb régiók esetében még közelebb áll a valósághoz, mint a fejletlenebb régiók esetében. Reális tapasztalati alapja van tehát annak a feltételezésnek, miszerint abban az esetben, ha más élenjáró régiókban megismételnénk a vizsgálatot, az alapmodellünk nagyobb valószínúséggel bizonyulna maradéktalanul helytállónak, mint gazdasági és infokommunikációs szempontból fejletlenebb régiók esetében. A III. modell vizsgálatakor ugyanis a fejlett régiókra vonatkozó eredmények a szektor kivételével minden változónál szignifikánsnak bizonyultak, míg a fejletlen régiók esetében a távmunkavégzés munkaszervezeti bevezetésének esélyeinél csak a szervezeti méret bír magyarázó erôvel.

Azt látjuk tehát, hogy modellünk a fejlettebb régiókban jobban múködik, ebból azonban nem következik, hogy a fejletlen régiók esetében nem lenne semmiféle relevanciája. Tulajdonképpen az volna meglepó, ha a régiók minden típusában ugyanazok a szabályszerüségek ugyanolyan módon múködnének. Ilyen homogén struktúrák valójában egyetlen országon belül sem jönnek létre, különösen nem európai léptékben értelmezett regionális összehasonlításban. Empirikus kutatási eredményeink alapján valószínúsíthető ugyanakkor, hogy a gazdasági fejlettség és az esetek nagy többségében ezzel párhuzamosan alakuló infokommunikációs fejlettség tekintetében homogén régióknak a távmunkavégzés munkaszervezeti bevezetésének esélyeire kiható jellegzetességei jobban hasonlítanak egymáshoz. Különféle regionális minták előfordulásával kell tehát számolnunk, sốt a távmunka bevezetése terén a regionális mechanizmusokhoz hasonló szektorális vagy méretarányos mechanizmusok fennállását is feltételezhetjük. Az ismertetett általános modell többé-kevésbe jól közelíti az említett almechanizmusok múködésmódjait, de természetesen nem teljes, mint ahogy nem is a teljességre törekvés szándékával készült. Fontos azonban leszögeznünk, hogy a megvizsgált regionális modellek esetében egyetlen esetben sem találtunk olyan ellenpéldát, amely a modell múködését cáfolta, vagy akár csak megkérdőjelezte volna.

\section{Összegzés}

Az alkalmazott modell beváltotta az elôzetes várakozásokat, ugyanakkor fontos megjegyezni, hogy a kutatás eredményeit három korlátozó tényező figyelembevételével szükséges értelmezni. Az elsố korlátozó feltétel a mintaválasztással kapcsolatos: a vizsgált régiók ún. „erős” régiók, amelyek gazdasági teljesítményük alapján az adott ország átlaga feletti teljesítménnyel rendelkeznek, némelyik régió ugyanakkor nemzetközi összehasonlításban is kimagaslónak számít, ami korlátokat szab az eredmények általánosíthatóságának. A kutatási eredmények második korlátozó feltétele, hogy kizárólag a távmunkavégzés munkaszervezeti jelenlétét vizsgáltam, nem vizsgáltam ugyanakkor a távmunkavégzés gyakorlatának konkrét tartalmát. Az általánosíthatóság harmadik korlátozó tényezője, hogy kizárólag a mikro-, kis- és középvállalati szektorra vonatkoztatható konklúziókkal szolgált, nem zárható ki ugyanakkor annak lehetősége, hogy a nagyvállalati szférában más, alternatív oksági mechanizmusok múködnek a távmunkavégzés bevezetésével kapcsolatban.

Elemzésem egy lehetséges magyarázó mechanizmust ragadott meg a távmunkavégzés munkaszervezeti bevezetésével kapcsolatban, nem kizárva a lehetőségét annak, hogy párhuzamos magyarázatok is létezhetnek. Mindent egybevetve - azértelmezési korlátok figyelem- 
bevétele mellett - kijelenthetô, hogy a modell hozzájárult a távmunkavégzés munkaszervezeti bevezetésének pontosabb megértéséhez, amennyiben új jelenségeket tárt fel és új magyarázó sémákat mutatott ki.

A távmunka elterjedtsége a mikro-, kis- és középvállalati szektorban Európa megvizsgált öt erôs régiójában jóval intenzívebb annál, mint azt feltételezni lehetett. A mintába került szervezeteknek több mint harmadánál megtalálható ez a típusú új munkavégzési forma. A logisztikus regressziós modell segítségével megállapítható, hogy a távmunkavégzés munkaszervezetbe való bevezetésére a vizsgált szervezeti háttértényezók közül öt tényezố gyakorol statisztikailag szignifikáns hatást. A származtatott független változók közül a termelési paradigma, az IKT-fejlettség mértéke, valamint a külsố szervezeti rugalmasság szintje, a közvetlen magyarázó változók közül ugyanakkor a szervezeti méret és a tevékenységi szektor hatása jelentős. Ezek közül a változók közül a három származtatott független változó rendelkezik a legnagyobb relatív magyarázó erővel a modellben. Az IKT-fejlettségnek van a legnagyobb magyarázó ereje, rögtön ezután következnek a termelési paradigmák, majd a külsố rugalmasság. A külsô rugalmasságtól nem sokkal marad el a szervezeti méret, majd a tevékenységi szektor változója. Ezek az adatok azt bizonyítják, hogy a származtatott magyarázó változók nem csupán szignifikáns tényezőnek számítanak a távmunkavégzés munkaszervezeti bevezetését magyarázó modellben, de relatív magyarázó erejük erôsebb a közvetlen szervezeti háttértényezók hatásánál. Indokolt volt tehát a közvetlenül nem mérhetô, latens szervezeti háttértényezőket is meghatározni, és a távmunkavégzés munkaszervezeti bevezetésének magyarázatával kapcsolatos modellbe bevonni.

A logit modell választ adott ugyanakkor további lényegi kérdésekre. A termelési paradigmákkal kapcsolatban az a konkrét elméleti kérdés merült fel az operacionalizálás során, hogy vajon a neofordi és posztfordi munkaszervezetek egy ideáltipikus skála két szélsố végét jelölik-e a távmunka bevezetésében. A logit egyenlet tanulságai alapján a neofordi és posztfordi modellhez tartozó szervezetek, a távmunkavégzés bevezetése szempontjából, valóban tekinthetók egy ideáltipikus skála két végpontjának, mivel a többi változó hatásának kontroll alatt tartása esetén a posztfordi paradigmához tartozó szervezeteknek a neofordihoz képest több mint kétszeres esélyük van a távmunkavégzés munkaszervezeti bevezetésére, ugyanakkor a hibrid termelési paradigmák a neofordi és posztfordi paradigma között helyezkednek el a távmunkavégzés bevezetésének esélyeit illetően. A kapott eredmények természetesen kizárólag a szervezeti magatartás távmunkavégzés bevezetésére vonatkozó részére vonatkoznak, s annak a feltételnek a szem előtt tartásával értelmezhetők, miszerint a kutatás nem tekintette közvetlen céljának a termelési paradigmák azonosítását, így a rendelkezésre álló adatok alapján a termelési paradigmákat közelítő indikátorokként használtam a modellben. Megjegyzendô ugyanakkor, hogy a termelési paradigmáknak a távmunkavégzés bevezetésével kapcsolatos magyarázó ereje annyira erôs, hogy statisztikai ellenvetések semmiképp nem hozhatók fel a modellben való szerepeltetésükkel kapcsolatban.

Az operacionalizálás során elkülönített két hibrid termelési paradigma közt feltételezett különbségeket nem sikerült verifikálni az alkalmazott modell révén. A modell eredményei alapján megállapítható tehát, hogy a két hibrid termelési paradigma kizárólag más szervezeti háttértényezókön keresztül fejti ki hatását a távmunkavégzés bevezetésére, vagyis - a rendelkezésre álló adatok alapján - nem bizonyítható inherens különbségek megléte a két kevert paradigma közt.

A szervezeti rugalmasság két típusával, a külső és belsố rugalmassággal kapcsolatban markáns különbségeket mutatott ki a modell. A távmunkavégzés munkaszervezeti bevezetése szempontjából ugyanis egyértelmúen a külső vagy munkaerô-piaci rugalmasság stratégiája bizonyult lényeges meghatározó tényezőnek. Minél inkább jellemzô adott szervezetre a külsô rugalmasság stratégiája, annál nagyobb esélye van a távmunkavégzés bevezetésére az adott szervezetnek. A külső rugalmassággal kapcsolatban tehát szintén egy erôs és tiszta hatásmechanizmust sikerült megragadni a távmunkavégzést meghatározó szervezeti háttértényezók közül. Az is igazolódott ugyanakkor, hogy a belsố vagy funkcionális rugalmasság, valamint a szervezet általános rugalmassága nincs statisztikailag szignifikáns hatással a távmunkavégzés munkaszervezeti bevezetésére. Ez az eredmény elméleti megfontolások alapján legfeljebb feltételezhetô volt, hiszen a külsố vagy munkaerô-piaci rugalmasság minőségi jellemzókkel leírható típusa, az ún. „teljesítménynövelő rugalmasság" - eleméleti kiindulásaink alapján - valószínúsíti a távmunkavégzés mint új típusú termelési rendszer alkalmazását. Eleddig empirikus bizonyíték hiányában azonban kizárólag a hipotetikus állítás rangjára tarthatott igényt ez a feltételezés.

A mikro-, kis- és középvállalatok vezetóinek attitúdjeivel, vagyis a fentebb pszichológiai determinizmusnak nevezett tényezókkel kapcsolatos kutatási eredmények szolgáltatták talán a legérdekesebb konklúziókat. A tanulmányozott méretkategóriában feltételezhető volt a vezetối attitúdök erôs hatása, ugyanis a laposabb szervezeti hierarchia és a döntéshozatalba épített társa- 
dalmi-szervezeti filterek hiánya miatt a vezetói beállítódások tompítatlanabb megjelenése volt prognosztizálható a vizsgált vállalati szegmensben a távmunkavégzés munkaszervezeti bevezetésével kapcsolatban. Ugyanakkor a modell eredményei alapján egyértelmúen alátámasztható, hogy a vezetői attitưdök nem befolyásolják szignifikánsan a távmunkavégzés munkaszervezeti bevezetését. Egyetlen, a kutatás során vizsgált attitűdkomponensnél sem mutatható ki statisztikailag jelentôs, távmunkavégzés bevezetésére gyakorolt hatás. Megjegyzendô ugyanakkor, hogy a vezetôi beállítódások vizsgálata önálló kutatásként is megállja a helyét. Reális lehetôség ugyanis, hogy léteznek olyan attitűdkomponensek, amelyekról a jelenleg vizsgált adatok alapján nem tudunk semmilyen kijelentéseket tenni, ugyanakkor hatással lehetnek a távmunka bevezetésére. Ilyenek például a csoportos munkavégzés (teammunka) igényével kapcsolatos vezetôi beállítódások, a szervezeti kultúra jellegzetességei, vagy olyan összetett tényezók, mint például a vezetési stílus. A vezetôi attitúdök tehát - a vizsgált modell eredményei alapján - nincsenek befolyással a távmunkavégzés bevezetésére, nem zárható ki viszont annak lehetősége, hogy a kutatás során nem vizsgált egyéb attitúdkomponensek jelentős hatást gyakorolnak a távmunka bevezetésére.

Az elemzés teljessé tétele érdekében a modellt más megközelítésben is teszteltem. Arra a kérdésre kerestem a választ, hogy a logisztikus modell révén megragadott összefüggések az egyes régiókban, külön-külön is fennállnak-e. A modellel kapcsolatos elemzéseknek ugyanis nem regionális különbségek összehasonlítása volt a célja, hanem olyan általános szervezeti tendenciák azonosítása, amelyek a távmunka bevezetésére hatást gyakorolnak. A kérdés megválaszolása érdekében annak megvizsgálására volt szükség, hogy a modell ugyanúgy „múködik-e” minden régióban, ahogyan azt az általános séma alapján várni lehet. Nem evidens ugyanis, hogy az egyes régiók különbözó társadalmi-gazdasági adottságai, kulturális összetétele és történelmi tradíciói, valamint makrogazdasági feltételei által meghatározott regionális mikrokörnyezetekben azonos módon fejtik ki hatásukat a modell által azonosított szervezeti háttértényezók a távmunkavégzés munkaszervezeti bevezetésével kapcsolatban. A modell múködésével kapcsolatos kérdés megválaszolása érdekében három különböző kiindulásból vizsgáltam meg azt, hogy a kiinduló modellben megfogalmazott mechanizmusok múködésére lehet-e ellenpéldát találni. Ezzel tulajdonképpen három különbözó kiindulás alapján próbáltam meg a felállított modellt és az általa szolgáltatott eredményeket cáfolni. Ezzel az eljárással a modell megalkotásakor megfogalmazott falszifikációs kritériumnak kívántam eleget ten- ni. A három alternatív tesztmodell egyikében sem találtam az eredeti modellben megfogalmazott magyarázó mechanizmusokkal ellentétes tendenciát, ami a modell relevanciáját támasztja alá.

Az alternatív tesztmodellek - az alapmodell múködóképességének bizonyításán túl - fontos kiegészító eredményeket is szolgáltattak. A közvetlen szervezeti háttértényezốk közül a szervezeti méret, a származtatott független változók közül pedig az IKT-fejlettség jelentik azokat a markáns tényezóket, amelyek az alternatív tesztmodellekben a legnagyobb valószínúséggel bizonyultak megbízható, szignifikáns magyarázó változóknak. Ezek jelentik tehát azt a két szervezeti háttértényezôt, amelyek hatásával a különböző társadalmi-gazdasági adottságoktól, kulturális és történelmi tradícióktól, valamint makro- és mikrogazdasági feltételektôl függetlenül mindenképpen számolni kell a távmunkavégzés munkaszervezeti bevezetését meghatározó háttértényezóknél. További fontos eredmény, hogy az alapmodell révén megragadott összefüggésrendszer a gazdaságilag, illetve infokommunikációs tekintetben fejlettebb régiók esetében valószínúleg jobban közelíti a valóságot, mint a fejletlenebb régiók esetében. Ez utóbbi eredményünkból azonban nem következik, hogy a fejletlen régiók esetében ne volna semmiféle relevanciája a modellnek. Mindössze annak a ténynek az igazolásáról van szó, hogy különféle régiókban a modell által megragadott szabályszerúségek eltérô módon fejtik ki hatásukat, vagyis különféle regionális minták előfordulásával kell számolnunk.

\section{Mit mond a modell a gyakorlat és vezetéselméleti kutatások számára?}

A megalkotott modellel mind gyakorlati, mind kutatási igényeknek meg kívántam felelni. A modell gyakorlati relevanciáját tekintve mindenekelótt fontos utalni arra, hogy az Európai Unió távmunkavégzés elterjesztésére irányuló törekvéseit egységes irányelvek jellemzik. Az Unió standard policy-k alapján igyekszik motiválni a különbözô régiókban múködő vállalkozásokat ennek az új típusú munkavégzési formának a bevezetésével kapcsolatban. A modell alapján kapott kutatási eredményeink azonban arról győztek meg bennünket, hogy a távmunka munkaszervezetbe történó bevezetésénél heterogén mechanizmusok múködésével is számolni kell. Ebból az a gyakorlati következtetés adódik, hogy a gazdasági és infokommunikációs értelemben eltéró fejlettségú, valamint eltérő strukturális adottságú régiók esetében a vállalkozások motiválásának egységesító törekvéseivel párhuzamosan eltérô irányelvek alkalmazására is szükség volna. 
A megalkotott modell egyik deklarált célja volt ugyanakkor az is, hogy további kutatások számára is kiindulásként szolgálhasson releváns kutatási kérdések megfogalmazása révén. A modell magyarázó ereje természetesen nem egyetemes, erôssége azonban, hogy viszonylag egységes keretek közé helyezi a távmunkavégzés bevezetésével kapcsolatos kérdéseket, $\mathrm{s}$ ezen kérdések némelyikével kapcsolatban konkrét válaszokat is megfogalmaz, számszerúsített formában. E válaszokkal együtt azonban további kutatásokat igénylő kérdéseket is felszínre hozott az alkalmazott modell, s úgy túnik, ezek száma nagyobb, mint a megválaszolt kérdéseké. Ezek közül tekintem át a legfontosabbakat az alábbiakban.

A logit modell eredményei által felszínre került kiegészítő vizsgálatokat igénylő elsô kérdéscsoport a termelési paradigmákkal kapcsolatos. Olyan tényezókról van szó, amelyek rendkívül jó magyarázó erejünek bizonyultak a távmunkavégzés bevezetésével kapcsolatban, így fontos volna szerepük részletekbe menó elemzése a távmunkavégzés munkaszervezeti bevezetésénél. A modell alapján kizárólag azt bizonyítottam, hogy a paradigmák szerepe és magyarázó ereje jelentôs a távmunka-bevezetés szempontjából. A kutatás során azonban egy olyan leegyszerúsített modell került alkalmazásra, amelyben csak négy paradigmatípus elemzésére került sor. Releváns kutatási igényként merül fel, hogy termelési paradigmák típusait pontosabban azonosítsuk, és részleteiben ragadjuk meg azokat a hatásokat, amelyeket a távmunkavégzés munkaszervezeti bevezetésére gyakorolnak.

Szintén a termelési paradigmákhoz kapcsolódó további kutatásokat igénylő speciális kérdés, hogy milyen szerepük van a hibrid termelési modelleknek a távmunka-bevezetésben. A modellhez kapcsolódó járulékos számítások alapján azt tapasztaltam ugyanis, hogy az elkülönített kétféle hibridtípushoz tartozó szervezetek között különbségek adódtak a távmunkavégzés előfordulási gyakoriságaiban, a többváltozós elemzések azonban már nem támasztottak alá szignifikáns eltéréseket. Ennek az lehet a magyarázata, hogy a kétféle hibrid paradigmában meglévő látszólagos különbségeket más szervezeti háttértényezók hatásai okozták, vagyis a hibridek közti eltérések nem tekinthetők inherens különbségeknek, mivel jól magyarázhatók egyéb szervezeti háttértényezókkel. Összességében tehát a két hibrid közti szignifikáns különbségekre vonatkozó hipotézist nem sikerült verifikálni, mindazonáltal érdemes volna a kérdés eldöntésével kapcsolatban további elemzéseket folytatni, ugyanis elképzelhető, hogy léteznek alternatív hibridparadigmák, amelyekkel kapcsolatban kimutatható különbségek állnak fenn a távmunkavégzés munkaszervezeti bevezetésére gyakorolt hatásokban. Ez a kérdés részben összefügg a termelési paradigmákkal kapcsolatos azon hipotetikus megállapítással, hogy a neofordi és posztfordi szervezetek egy ideáltipikus skála végpontjaiként is értelmezhetók, hiszen amenynyiben elfogadjuk ezt a hipotézist, úgy válaszra vár annak a kérdésnek a megválaszolása, hogy milyen típusú termelési paradigmák helyezkednek el a skála köztes pontjain.

További kutatások szükségesek annak a kérdésnek az eldöntéséhez is, hogy pontosan mi a kétféle szervezeti rugalmasság egymáshoz való viszonya a távmunka bevezetésével kapcsolatban? Vajon tényleg kétféle rugalmasságtípusról, vagy egy jóval bonyolultabb rugalmasságtipológia múködésérốl van-e szó a távmunka bevezetésére hatást gyakorló tényezókben? Valószínúsíthetô ugyanis, hogy a belső rugalmasság - vagy annak valamilyen, jelen kutatás során nem vizsgált altípusa - befolyással van a távmunkavégzés munkaszervezeti bevezetésére. A belső rugalmasságnak különösen a „munkaszervezeti rugalmasság” altípusával kapcsolatban feltételezhetố a szóban forgó összefüggés. További kutatások szükségesek azonban annak eldöntésére, hogy pontosan milyen mechanizmusok múködnek a belsố rugalmasság és távmunkavégzés munkaszervezeti bevezetésének összefüggésével kapcsolatban.

A vezetối attitúdök kérdésköre az a területet, amely talán a legtöbb nyitott kérdést hagyta maga után. A vizsgált attitúdkomponensek ugyanis a kutatási eredmények tapasztalatai alapján vagy nincsenek egyáltalán semmilyen hatással a távmunkavégzés munkaszervezeti bevezetésére, ahol pedig statisztikailag szignifikáns hatást lehet feltételezni, ott ellentmondásos eredmények tapasztalhatók. Megnyugtató módon tehát egyáltalán nem zárhatjuk le a vezetôi attitúdök téma szempontjából értelmezett jelentôségét. További kutatásokat szükséges folytatni a kérdés világos megválaszolásának érdekében, nehezen képzelhetô el ugyanis, hogy a vizsgált vállalati szegmensben egyáltalán ne gyakorolnának befolyást a vezetôi attitúdök a távmunkavégzés bevezetésére. Elméleti kiindulások alapján ugyanis pontosan ennek ellenkezóje valószínúsíthetô. A jelen kutatásban vizsgált attitúdszegmensek azonban - a többi szervezeti háttértényezóhöz képest - elenyészó befolyással bírnak, nem mutatható ki szignifikáns hatásuk. További kutatások során szükséges annak tisztázása, hogy a vezetôi attitúdöknek pontosan milyen komponensei járulnak hozzá a távmunkavégzés munkaszervezeti bevezetéséhez a vizsgált vállalati méretkategóriákban.

Az IKT-fejlettség a modell egyik legerósebb hatást gyakorló, és az alternatív tesztmodellekben is többnyi- 
re szignifikáns hatást mutató háttértényezője. A kutatás során azonban kizárólag az infokommunikációs technológiai fejlettség szervezeti szintjét vizsgáltuk, nem gyújtöttünk információkat arról, hogy az egyes szervezetekben rendelkezésre áll-e az infokommunikációs technológiák magas szintú használatára képes munkaerô. E nélkül ugyanis az IKT-fejlettség távmunkabevezetésre gyakorolt hatása mindössze potenciális tényezôként értelmezhető. Ez utóbbi kutatási kérdés természetesen már egy másik kiindulást foglal magában, amennyiben az „elektronikus múveltség” (eliteracy) és a vállalati képzés távmunkavégzés bevezetésében betöltött szerepére vonatkozik.

A tesztmodellek eredményei is további kutatási kérdéseket implikálnak. Különféle regionális minták előfordulásával kell számolnunk a távmunkavégzés munkaszervezeti bevezetésével kapcsolatban. A távmunka által érintett üzleti funkciók vagy tevékenységek szerkezete, a helyi/regionális munkaerő-piaci feltételek, a nemzetközi szabályozási keretrendszer és az adott regionális foglalkoztatási helyzet, a vállalati kultúra jellemzői, a szervezet tevékenységi szektora és mérete, a regionális irányelvek és az infrastruktúra rendelkezésre állása egyaránt hatással vannak a távmunkavégzés munkaszervezeti bevezetésére. Ezeket a tényezóket egyáltalán nem vizsgáltam a kutatás során, mivel egy ilyen megközelítés már kilépést jelentett volna a modellkísérlet elôre definiált keretei közül. További kutatások szükségesek tehát annak a kérdésnek a megválaszolásához, hogy az említett tényezók pontosan milyen módon vannak hatással a távmunkavégzés munkaszervezeti bevezetésére, valamint hogy lehet-e ezeket a faktorokat egy olyan típusú kvantitatív modellkísérletbe bevonni, amely jelen tanulmány alapját képezte.

\section{Lábjegyzet}

${ }^{1}$ Köszönetemet fejezem ki Bokor Attilának (Budapesti Corvinus Egyetem, Vezetéstudományi Intézet), aki a cikk korábbi változatához füzött hasznos kérdéseivel és megjegyzéseivel hozzájárult a cikk elkészítéséhez.

${ }^{2}$ A tanulmány elkészítését az Európai Unió által támogatott E-Society Gap Assessment Projekt: EGAP címú kutatásban való részvételem tette lehetôvé. A kutatásról rendelkezésre álló tanulmányok és kutatási jelentések a http://www.egap-eu.com oldalon olvashatók. A kutatásban a következó intézmények kutatói vettek részt, hat országból: La Sapienza Egyetem (Róma); MTA - Szociológiai Kutatóintézet (Budapest), Tamperei Egyetem (Tampere); Brunel Egyetem (London); Futuribles Intézet (Párizs); Distance Expert Ltd. (Párizs); ICCT École Centrale de Lyon (Lyon); ESC Grenoble (Grenoble), valamint (társult partnerként) Tokiói Egyetem (Tokió).

${ }^{3}$ Európai szinten egyetlen jelentôs modellkísérletról van tudomásom (Bates - Huws, 2002), amely azonban egyfelől más vállalati méretkategóriákra vonatkozik, másfelől alapkoncepcióját tekintve is több tekintetben különbözik a jelen tanulmányban alkal- mazott modellkísérlettól, Huws és Bates ugyanis az ún. „üzleti funkciók" felől közelítették meg a témát.

4 A ,determinizmus” kifejezést itt kizárólag abban az értelemben használom, amilyen értelemben a kvantitatív elemzések legtöbbje. Nem gondolom, hogy a távmunkavégzés bevezetésének, mint szervezeti jelenségnek, kizárólag egy, és csak egy magyarázata létezhet. A feltárt összefüggések természetesen további, mélyebb - például kvalitatív - elemzések igényét vetik fel.

${ }^{5}$ A külsô és belső rugalmasság, valamint a termelési paradigmák összefüggését 2001-ben használtam először egy kistérségi szervezetkutatás kapcsán (Keszi, 2001). 2003-ban, a kutatás megismétlése során, ismét alkalmazhatónak bizonyult a fogalomrendszer (Keszi, 2003; Keszi - Makó - Simonyi, 2003).

${ }^{6}$ A táblázat elkészítésénél Makó - Simonyi (2003) munkájában szereplő felosztást módosítottam.

${ }^{7}$ A viták rövid áttekintését ld. Makó (2002).

${ }^{8}$ Csak néhány példa a szervezetszociológia fogalmi sokszínúségéból: neofordi és posztfordi munkaszervezet, diverzifikált minőségi termelés, rugalmas tömegtermelés, rugalmas specializáció (Alasoini et al., 1994; Regini, 1995; Huys et al., 1999).

${ }^{9}$ A munkafolyamat-iskolához tartozó kutatók érdeklődésének középpontjában a munkaszervezettel és a munkavégzés módjával kapcsolatban olyan kérdések állnak, mint például a munkaügyi kapcsolatok átalakulása, a szervezeti kontroll módosulása és az új termelési paradigmák megjelenése. Az irányzat részletesebb áttekintését ld. Makó (2002).

${ }^{10}$ Grammatikai tekintetben is konzekvensen használom az előtagokat, hiszen a görög eredetú „,neo-” (új) a szóösszetétel előtagjaként a vele összetett fogalom (jelen esetben fordizmus) újbóli, kissé módosult felbukkanását, míg a latin eredetư ,poszt-” a szóösszetételek előtagjaként a hozzá kapcsolt fogalom utáni, az ahhoz képest módosult dolgot jelent.

${ }^{11}$ Az olasz és a francia kutatói team az alapmintát kiegészítette nagyvállalatokkal (>249 fó) is, ezeket a vállalatokat azonban - az ismertetett módszertani elveknek való megfelelés érdekében - kihagytam a jelen elemzésból, ebben a tanulmányban tehát kizárólag a 250 fónél kevesebb alkalmazottat foglalkoztató vállalati méretkategóriára vonatkozó elemzések szerepelnek.

12 Ilyen például a vállalat pénzügyi helyzete, munkaerő-szerkezete, növekedési üteme, szervezeti kultúrája és még egy sor rendkívül fontos tényezó.

${ }^{13}$ A többváltozós elemzési technikák közül a lineáris regresszió, illetve a diszkriminancia-analízis adódik kézenfekvő technikaként. Mivel azonban a lineáris regresszió nem képes megnyugtató módon kezelni kétértékú függố változónkat (van/nincs távmunka), a diszkriminancia-analízis pedig nem fogad be alacsony mérési szintû független változókat (a rendelkezésre álló közvetlen és származtatott magyarázó változók többsége nominális/ordinális mérési szintû́), a logit modell tûnt a legésszerúbb választásnak a távmunkavégzés bevezetésének magyarázatához.

${ }^{14}$ A kétváltozós elemzések során $12+1$ (12 + régió) változó hatását vizsgáltam meg. A régió hatása szintén szignifikánsnak bizonyult a logisztikus regressziós elemzés során, ezt azonban ebben a modellben nem szerepeltetem, ugyanis hatása annyira erôs, hogy célszerú külön elemzésben megvizsgálni (ld. alább). A legalább 5\%-os statisztikai szignifikanciát nem mutató változókra vonatkozó adatokat nem közlöm, kizárólag a végsô, statisztikailag megbízhatónak bizonyult változókkal kapcsolatos elemzéseket teszem közzé.

${ }^{15} \mathrm{Az}$ itt használt matematikai esély fogalom természetesen nem egyezik meg a hétköznapi életesély fogalmával. Míg a hét- 
köznapi nyelvhasználat többnyire a valószínúség fogalmával hozza kapcsolatba az esély értelmezését, addig az itt használt esélyfogalom két komplementer-valószínúség (valaminek a bekövetkezése /be nem következése) hányadosával egyezik meg. Ennek figyelembevételével: Az esélyhányados két esély hányadosát adja, így alkalmas két változó egymáshoz való viszonyának a jellemzésére. A táblázatban az esélyhányados /Exp (B)/ azt fejezi ki, hogy az adott kategóriába tartozó szervezeteknek hányszoros esélyük van a távmunka bevezetésére a referenciakategóriába tartozó szervezetekhez képest - amennyiben a modellben szerepló többi változó hatását kontroll alatt tartjuk (ez az érték a regressziós paraméter exponenciális értéke: $\operatorname{Exp}(B)=\mathrm{eB})$ A referencia-kategória azt a kategóriát jelenti, amelyhez az adott változó többi kategóriáját viszonyítjuk. Amennyiben nem kategoriális változókról van szó (a modellben ilyen az IKT-fejlettség), az esélyhányados azt fejezi ki, hogy a változó értékének 1 egységgel való növekedése esetén hányszorosára változik a távmunkavégzés bevezetésének esélye.

${ }^{16}$ Példák az összetettebb változók képzési algoritmusaiból:, amelyek magas korrelációt mutattak a modellben használt IKT változóval, de jelen tanulmányban nem használtam óket.

$$
I_{\text {sta } 1}=\sum_{i=a}^{g} X_{i} \cdot\left(1-P_{i}\right) ; I_{\text {sta } 2}=\sum_{i=a}^{g} X_{i} \cdot\left(\frac{1}{P_{i}}\right)
$$

Jelölés: $\mathrm{X}_{\mathrm{i}}\left(X_{a} \ldots X_{g}\right): \mathrm{Az}$ adott IKT-eszköz jelenléte a vállalati gyakorlatban. Dummy változók, lehetséges értékeik: $O=$ nem használják; 1 = használják. $P_{i}\left(P_{a} \ldots P_{g}\right)$ : Az adott IKT eszköz előfordulási gyakoriságai a teljes mintában.

${ }^{17}$ Az esélyhányados matematikai jelentése egyébként a következő: A 19 értékú IKT fejlettségi index 1 egységgel való növekedésével 1,095-szeresére nó a távmunka bevezetésének esélye.

${ }^{18}$ A Wald érték szintén alkalmas a független változók hatásának jellemzésére, hátránya azonban, hogy magas B érték esetén megnó a valószínúsége a hamis nullhipotézis $(\mathrm{B}=0)$ elfogadásának. Ennek a hibának a kiküszöbölése érdekében határoztam meg az $\mathrm{R}$ mutatót.

$\mathrm{R}= \pm \sqrt{\frac{\text { Wald }-2 \text { dff }}{-2 \text { L.L. }}}$ ahol $\mathrm{R}$ felveszi a B érték előjelét

${ }^{17}$ A II-IV. modellek magyarázó változóit - az IKT-fejlettség kivételével - dummy változókká alakítva vittem be a logisztikus regressziós egyenletbe, hogy az adatok minél jobban áttekinthetók legyenek. Az IKT-fejlettség változója eredeti formájában maradt.

\section{Felhasznált irodalom}

Alasoini, T. et al. (1994): Manufacturing Change. Interdisciplinary Research and New Modes of Operation in Finnish Industry. Work Research Unit, University of Tampere, Finland

Bates, P. - Huws, U. (2002): Modelling EWork in Europe. Estimates, models, and forecasts from the EMERGENCE Project. Institute for Employment Studies, Brighton, UK

Clegg, S. (1990): Modern Organisations: Organisation Studies in a Postmodern World. London: Sage

Dahrendorf, $R$. (1986): Labour Market Flexibility. Report by High Level Group Expertise to the Secretary General. OECD, Paris
Dahrendorf, R. (1995): Economic Opportunity, Civil Society and Political Liberty. Discussion Papers 58. United Nations RISD, New York

Dore, R. (1986): Flexible Rigidities: Industrial Policy and Structural Adjustment in the Japanese Economy, 19701980. Adhlone Press, London

Harris, M. (1998): Rethinking Virtual Organisation. In: Jackson, P. - Van Der Wielen, J.M. /ed./: Teleworking: International Perspectives - From Telecommuting to the Virtual Organisation. Routledge, London, 1998, p 74-93

Huys, R. - Sels, L. - Van Hootegem -Bundersvoet, J. Hendenrickx, E. (1999): 'Towards Less Division of Labour? New Production Concepts in Automotive, Chemical, Clothing and Machine Tool Industies", In: Human Relations, Vol. 52, No.1, p 67-93

Kern, H. - Schumann, M. (1984): Das Ende der Arbeitstellung. Rationalisierung in der industriellen Produktion. C.H. Beck Verlag, München

Keszi R. (2002): Magatartástudományi szervezetdiagnosztika. In: Vezetéstudomány 2002/4. 16-36. old

Keszi, R. - Makó, Cs. - Illéssy, M. - Mester, D. (2003): Report on the Market Surveys in Five Countries (Hungary, Poland, Latvia, Lithuania, Romania). E3Work Project Supported by the European Commission IST Program, Institute of Sociology, Budapest

Keszi, R. (2003): Létszámfejlesztés, versenyképesség és az emberierőforrás-gyakorlat jellemzői. Készült a „Kistérségi modell a gazdaság és a szakképzés együttmúködésére, különös tekintettel a nagy foglalkoztatók képzési igényeire és az Új Gazdaság kihívásaira” c. kutatás keretei között. MTA Szociológiai Kutatóintézet, Budapest

Keszi, R. (2005): A távmunkavégzés munkaszervezeti bevezetését meghatározó tényezők a kkv szektorban. www. krolify.hu/adatok/File/tavmunka_MSZT_konf_2005_ nov_15_krolify.pdf

Keszi, R. - Makó, Cs. - Illéssy, M. - Mester, D. (2003): Report on the Market Surveys in Five Countries (Hungary, Poland, Latvia, Lithuania, Romania). E3Work Project Supported by the European Commission IST Program, Institute of Sociology, Budapest

Liker, J.K. - Fruin, W.H. - Adler, P.S. /eds./(1999): Remade in America (Transplanting and Transforming Japanese Management System). Oxford University Press, New York

Makó, Cs. - Simonyi, Á. (1990): Társadalmi terek és az autonóm cselekvés lehetőségei - A társadalmi változások többdimenziós megközelítése. MTA Szociológiai Kutatóintézet, Budapest

Makó, Cs. - Simonyi, Á. (2001): „A munkaerô- és tudásfelhasználás mintáinak kutatása, a foglalkoztatási szerkezet pontos leírása a dunaújvárosi kistérségben, különös tekintettel a Dunaferr technológiaváltásából eredő jelentősebb létszámleépítésre" - (OFA LXXXVII - 62/99. számú kutatási szerződés alapján végzett kutatás beszámolója), MTA Szociológiai Kutatóintézet, Budapest 
Makó, Cs. - Simonyi, Á. (2003): A tudásfelhasználás rugalmasságának felértékelődése. In: Makó Cs. - Simonyi Á. /szerk./: A munka és a párbeszéd új paradigmái. Országos Foglalkoztatási Közalapítvány, Budapest

Makó, Cs. (2002): „Paradigmaváltás a munkafolyamatban: poszt-fordizmus helyett neo-fordizmus. Változások a tömeggyártás munkaszervezetében és a vállalati munkaügyi kapcsolatokban. (Egy nemzetközi projekt tapasztalatai)" In: Harvard Business Manager, 2002/1.

Makó, Cs. - Keszi, R. (2002): Does E-Work Indicate Differences in Development of Business Organisations in East Central Europe? Paper Presented for the "The World, The Workplace and We the Workers - E-Work in the Global Economy" International conference on the impact of ICT applications on delocalisation of work, working conditions and workers. 16-17 April 2002, International Trade Union House, Brussels, Belgium http://www.emergence.nu/events/brussels/makoework.pdf

Makó, Cs. - Keszi, R. (2003): eWork in EU Candidate Countries. Institute for Employment Studies, Brighton, UK

Makó, Cs. - Keszi, R. - Mester D. (2004): „Munkáltatói vélemények a távmunka bevezetésének előfeltételeiról és gyakorlatáról” In: Társadalomkutatás 2004/22/ 2-3. szám

McGrath, P. - Houlihan, M. (1998): Conceptualising Telework: Modern or Postmodern? In: Jackson, P. -
Van Der Wielen, J.M. /ed./: Teleworking: International Perspectives - From Telecommuting to the Virtual Organisation. Routledge, London, 1998, p 56-74

Neumann L. (1988): „Piaci viszonyok az üzemi béralkuban” In: Gazdaság, 4. sz.

Piore, M. - Sabel, C. (1984): The Second Industrial Divide. New York, Basic Books.

Regini, M. (1995): "Firms and Institutions: Demand for Skills and Their Social Production in Europe." In: European Journal of Industrial Relations, 1-2, p 191-202

Sabel, C. (1982): Work and Politics - The Division of Labour in Industry. Cambridge University Press, London

Sandberg, A. led./ (1995): Enriching Production Perspectives on Volvo's Uddevala Plants as an Alternative to Lean Production. Aldershot, Evebury

Stark, D. (1988): „Osztályozás és szervezeti béralku a belsô munkaerőpiacon" In: Gazdaság, 4. sz.

Visser, J. (1999): The First Part-time Economy in the World - Does it Work? Paper Presented at the Euro-Japan Symposium on the Development of Atypical Employment and Transformation of Labour Markets. March 1999, Tokio

Cikk beérkezett: 2007. 9. hó

Lektori vélemény alapján átdolgozva: 2007. 11. hó

KEDVES OLVASÓ!

NE FELEJTSE EL MEGÚJÍTANI ELÓFIZETÉSÉT

EZ ÉVRE IS! 